\title{
Physical properties of aerosols at Maitri, Antarctica
}

\author{
C G Deshpande and A K Kamra \\ Indian Institute of Tropical Meteorology, Pune, India.
}

\begin{abstract}
Measurements of the submicron aerosol size distribution made at the Indian Antarctic station, Maitri $\left(70^{\circ} 45^{\prime} \mathrm{S}, 11^{\circ} 44^{\prime} \mathrm{E}\right)$ from January 10 th to February 24 th, 1997, are reported. Total aerosol concentrations normally range from 800 to 1200 particles $\mathrm{cm}^{-3}$ which are typical values for the coastal stations at Antarctica in summer. Aerosol size distributions are generally trimodal and openended with a peak between 75 and $133 \mathrm{~nm}$ and two minima at 42 and $420 \mathrm{~nm}$. Size distributions remain almost similar for several hours or even days in absence of any meteorological disturbance. Total aerosol concentration increases by approximately an order of magnitude whenever a low pressure system passes over the station. Based on the evolution of aerosol size-distributions during such aerosol enhancement periods, three types of cases have been identified. The nucleation mode in all three cases has been suggested to result from the photochemical conversion of the DMS emissions transported either by the marine air or by the air from the ice-melt regions around Maitri. Subsidence of midtropospheric air during the weakening of radiative inversion is suggested as a possible source of the nucleation mode particles in the third case. Growth of the nucleation mode particles by condensation, coagulation and/or by cloud processes has been suggested to be responsible for other modes in size distributions.
\end{abstract}

\section{Introduction}

The background aerosols play an important role in the radiation budget as they directly interact with the solar terrestrial radiation. They influence the budget indirectly also by acting as cloud condensation/ice nuclei to form water droplets/ice crystals and thus involving them in the cloud formation processes. Slight changes in their properties and/or concentration may thus cause large changes in the global atmospheric processes leading to a global climatic change (Charlson et al 1987). Therefore, a continuous monitoring or at least occasional checking of the background concentration of aerosol particles needs to be made at sites free from the anthropogenic pollution. The vast ice sheet of Antarctica has no or very little human activity and has less than $2 \%$ of bare land exposed to the atmosphere. Moreover, the air circulation over Antarctica prevents the direct transport of air from the lower latitudes through the lower troposphere. Therefore, it provides an ideal site to study the background aerosols.

Observations at a coastal station in Antarctica are more complex than on a high polar plateau and thus more difficult to interpret. The $\mathrm{CN}$ concentrations at the coastal stations are $2-5$ times higher than at the south pole. The strong continental drainage flows, the baroclinic disturbances generated over the southern ocean and circulating around the continent of Antarctica, the generation and transport of DMS in the ice-melt regions are the additional possible sources for the aerosols at the coastal stations.

Submicrometer particles are suspended throughout the troposphere and lower stratosphere over the ice sheet of Antarctica. Their concentration shows a strong seasonal variation, being as low as a few $\mathrm{cm}^{-3}$ in winter to several thousands $\mathrm{cm}^{-3}$ in summer (Hogan 1975). Such strong seasonality has also been observed in condensation nuclei concentration at the coastal stations of Syowa (Iwai

Keywords. Antarctic aerosols; coastal aerosols; aerosol size distribution; aerosols transport with polar lows; Maitri aerosols. 
1979; Ito 1980, 1983, 1985; Ito and Iwai 1981), Ross Island (Shaw 1986), Georg-von-Neumayer (Jaenicke and Stingl 1984; Jaenicke et al 1992) and Mawson (Gras and Adriaansen 1985). Most of the Antarctic aerosol has been found to be sulphate. The prevalence of sulphate particles in the sunlit months provides a circumstantial evidence that these particles are produced by photochemical processes, the most plausible precursors of $\mathrm{SO}_{2}$ being the inert gases such as COS, $\mathrm{CS}_{2}$ etc. (Shaw 1979, 1988). Jaenicke et al (1992) report that although multi-modal size distributions definitely exist in their observations, averaging of distributions might transform them to single-mode shape because of the varying locations of modes. Similar to the observations of Ito (1982), they observe a maximum at $80 \mathrm{~nm}$ diameter but do not confirm the maximum at $10 \mathrm{~nm}$. Their averaged sizedistributions show monodisperse distributions with maximum diameters in the range of 30 to $90 \mathrm{~nm}$ range. Since the gas-to-particle conversion process is expected to produce particles of about $2-3 \mathrm{~nm}$ diameter only, Jaenicke et al (1992) concludes that further studies are needed to explain the production mechanism of the Antarctic aerosols.

During the first Aerosol Characterisation Experiment (ACE2), simultaneous measurements of precursor gases and ultrafine particle concentrations confirm the photochemical formation of new particles in the outflow from cumulus clouds (Clark et al 1998) and directly downwind of penguin colonies on Macquarie island (Weber et al 1998). Bates et al (1998) observed that new particles mix into the marine boundary layer after cold frontal passages and during periods of synopticscale subsidence and convective mixing between the free troposphere and the marine boundary layer. In addition to their growth through condensation, these submicron particles can cycle through non-precipitating clouds many times before their removal from the air through rain (Hoppel et al 1986). Inside the cloud layer, particles are activated and form cloud droplets which absorb gas-phase species and smaller particles. On evaporation, the cloud droplets leave a residue which is larger than the original particle. Consequently, the modified aerosol size distribution contains two submicron peaks, one due to homogeneous nucleation and the other due to cloud cycling.

Another source for nucleation of new particles has been observed in the clear marine coastal atmosphere under conditions of low tide and solar irradiation (O'Dowd et al 1998, 1999). Observations of Bigg et al (2001) during the Arctic Ocean Expedition (AOE-96) show that dynamical processes within the lower part of the atmospheric boundary layer exert a large influence on nearsurface concentrations of gases and aerosols in the central Arctic. Their observations also show very large but transient changes in Aitken mode particles $(21-50 \mathrm{~nm})$ concentrations during the frontal passage. Jaenicke et al (1992) suggest that the sudden increases in aerosol concentration, regularly observed at their station, might be explained with subsiding air. Another source responsible for these sudden increases may be the sea-salt particles of secondary origin i.e., the particles which are incorporated into clouds, precipitated, and later re-suspended from the snow surface as lifted ice crystals with increasing wind velocities. This mechanism as suggested by Hogan (1975) and Jaenicke and Matthias-Maser (1992) may be a noticeable source in Antarctica.

In this paper, we report our measurements of the submicron aerosol size-distribution made at the Indian station, Maitri $\left(70^{\circ} 45^{\prime}, 52^{\prime \prime} \mathrm{S}, 11^{\circ} 44^{\prime}, 03^{\prime \prime} \mathrm{E}\right.$, $117 \mathrm{~m}$ above $\mathrm{msl}$ ), during the XVI Indian Antarctic Expedition in the summer of 1996-97. The results are interpreted in terms of the local meteorological and synoptic conditions.

\section{Instrumentation and sampling}

The aerosol measurements were carried out with a TSI 3030 Electrical Aerosol Analyser (EAA) system. It measures the size distribution of particles of diameter 3 to $1000 \mathrm{~nm}$ in 10 different size ranges. The accuracy of measurements with this instrument is very large for the large particles but is not sufficient for the lowest 2 channels i.e., for 3 and $7 \mathrm{~nm}$ diameter-ranges due to the limitation of operating the instrument where the rate of generation of photo-chemically generated aerosols is highly variable. Therefore, the contributions from these two channels are not considered in this analysis. Accuracy of measurements with the EAA system, however, increases with particles size (Liu and Pui 1975). Since the noise due to electronics in the EAA system is less than $\pm 1 \mathrm{mV}$, number concentration in the channels with midpoint diameters $13,23,42,75,133,237,422$ and $750 \mathrm{~nm}$ may have a standard deviation of $417,167,87,44,24,12,7$ and 4 particles $\mathrm{cm}^{-3}$, respectively. The error due to the variability in number concentration decreases when 5 to 10 individual measurements are averaged. The EAA system was operated after every 3 hours to collect 5 size-distribution samples and the data were stored in a PC. In the present analysis, we use the average of 5 samples collected after every 3 hours. The inlet of the EAA system was cleaned at least once a day to minimise any accumulation of sea salt, snow or dust at the inlet. This cleaning frequency was found to be adequate as no significant difference was observed in the measurements made before or after the cleaning. 
Background aerosol concentrations can be derived from the measurements of the atmospheric electric conductivity over open oceans (Cobb and Wells 1970; Misaki et al 1972; Kamra and Deshpande 1995; Kamra et al 2001). Simultaneous measurements of conductivity and aerosols concentrations were made during the onward cruise to Antarctica with a Gerdiens apparatus (Dhanorkar and Kamra 1992) and the EAA system, respectively. Comparison of the data obtained on five consecutive days between $41^{\circ} \mathrm{S}$ and $55^{\circ} \mathrm{S}$ where the conditions for validity of the conductivity-aerosol concentration relation are met, showed that the two values of aerosol concentration did not differ by more than $15 \%$ of the measured values. The agreement between the two techniques is very good considering that the particle size-ranges measured with the two techniques may differ.

\section{Measurement site and weather}

Antarctica has only about $2 \%$ of its area free of ice. The Indian station, Maitri is located in the Schirmacher oasis in the Dronning Maud Land, east Antarctica. The east-west trending Schirmacher oasis is exposed over an area of approximately $35 \mathrm{~km}^{2}$ with $16 \mathrm{~km}$ length and a maximum width of $2.7 \mathrm{kms}$ in the central part. It lies at an altitude of $117 \mathrm{~m}$ above mean sea level with steep cliffs towards the ice-shelf and is covered by polar ice on the southern side. The area is dominated by sandy and loamy sand type of soil and the water holding capacity of the soil varies between 28 and $52 \%$ (Ramteke et al 1997). The northern side of Maitri has a steep slope, frozen lakes and ice-shelf extending to nearly $90 \mathrm{~km}$ in the summer. The southern side of the Schirmacher oasis is overridden by polar ice-front and the ice-rock interface fluctuates with season. So, on both the northern and southern sides of Maitri, the ice-melt region exists at this time of the year at about $0.5 \mathrm{~km}$ from the station.

Figure 1 shows a map of the Maitri station and its surroundings. The scatter polar diagram of 3hourly surface winds for the period of observations at Maitri is also plotted in figure 1. The aerosol measurements were carried out in a summer hut, namely Tirumala. Inlet of the air sampling stainless steel tube was projected out at a height of $2 \mathrm{~m}$ above ground through a window such that most of the time, it faces the persistent wind direction. The loss of aerosol particles by diffusion to the walls of the intake tube, as calculated from Fuch's (1964) formula, is less than $7 \%$ for $1 \mathrm{~nm}$ particles and less than $1 \%$ for $13 \mathrm{~nm}$ particles. The single-storey building of Maitri station and other structures such as generator huts, gas plant, incinerator, were about $150-200 \mathrm{~m}$ away in the northeast direction from the site of the measurements so that any pollutant released from them had little or no chance of reaching the site of measurements with the prevalent winds. The aerosol size-distribution measurements were carried out at Maitri from January 11th to February 24th, 1997.

Figure 2 illustrates the variations of meteorological parameters based on the 3-hourly observations taken by the India Meteorological Department, for the period of stay at Maitri. During this period, the maximum air temperature observed in the second week of January is $+6.8^{\circ} \mathrm{C}$ and it decreases to a minimum of $-11^{\circ} \mathrm{C}$ in the end of February, 1997. The Antarctic winds are characterised by high directional constancy but show large variations in speed. The dominant wind direction is southeast or south-southwest i.e., the measurement site is generally not likely to be influenced by any emission from the Maitri building or its surroundings. The sea-level pressure, recorded during this period is the lowest $971.1 \mathrm{hPa}$ on February 13th, 1997 and the highest $1001.8 \mathrm{hPa}$ on February 19th, 1997. The cloud cover over Maitri occurs mainly under the influence of sub-polar low pressure systems moving east-southeastward between $65^{\circ}$ and $70^{\circ} \mathrm{S}$ and shows alternating sequence of clear sky changing over to the overcast and then again clearing as the system moves away. Changes in cloud amount are often rapid, especially as the system approaches or moves away. Usually, high clouds, cirrus in bands, appear first. They grow denser and eventually result in the cirrostratus overcast. Later, altostratus followed by stratocumulus overcast generally results. Rarely, isolated orographic clouds also appear due to the southerly wind blowing over comparatively shallow mountain ranges. Since the winds blow over a vast ice plateau, the air is very dry and thus the cloud amount varies from just a few specs to 2 octas. The height of altocumulus cloud over Maitri often falls in the low category. Sometimes, cumulus clouds with little vertical development are also seen at the northern horizon.

\section{Aerosol concentrations at Maitri}

Also shown in figure 2 are 3-hourly values of total aerosol concentration obtained by adding the number concentrations in eight channels for particle sizes of 10 to $750 \mathrm{~nm}$ diameter. Total aerosol concentration does not show any diurnal variation and is generally less than 1000 particles $\mathrm{cm}^{-3}$ in absence of some meteorological phenomena. Concentrations of condensation nuclei of the same order have also been reported in summer months at different Antarctic coastal stations, e.g., by Gras and Adriaansen (1985) at Mawson $\left(67.6^{\circ} \mathrm{S}, 62.9^{\circ} \mathrm{E}\right)$, Shaw (1986) at Ross Island, 


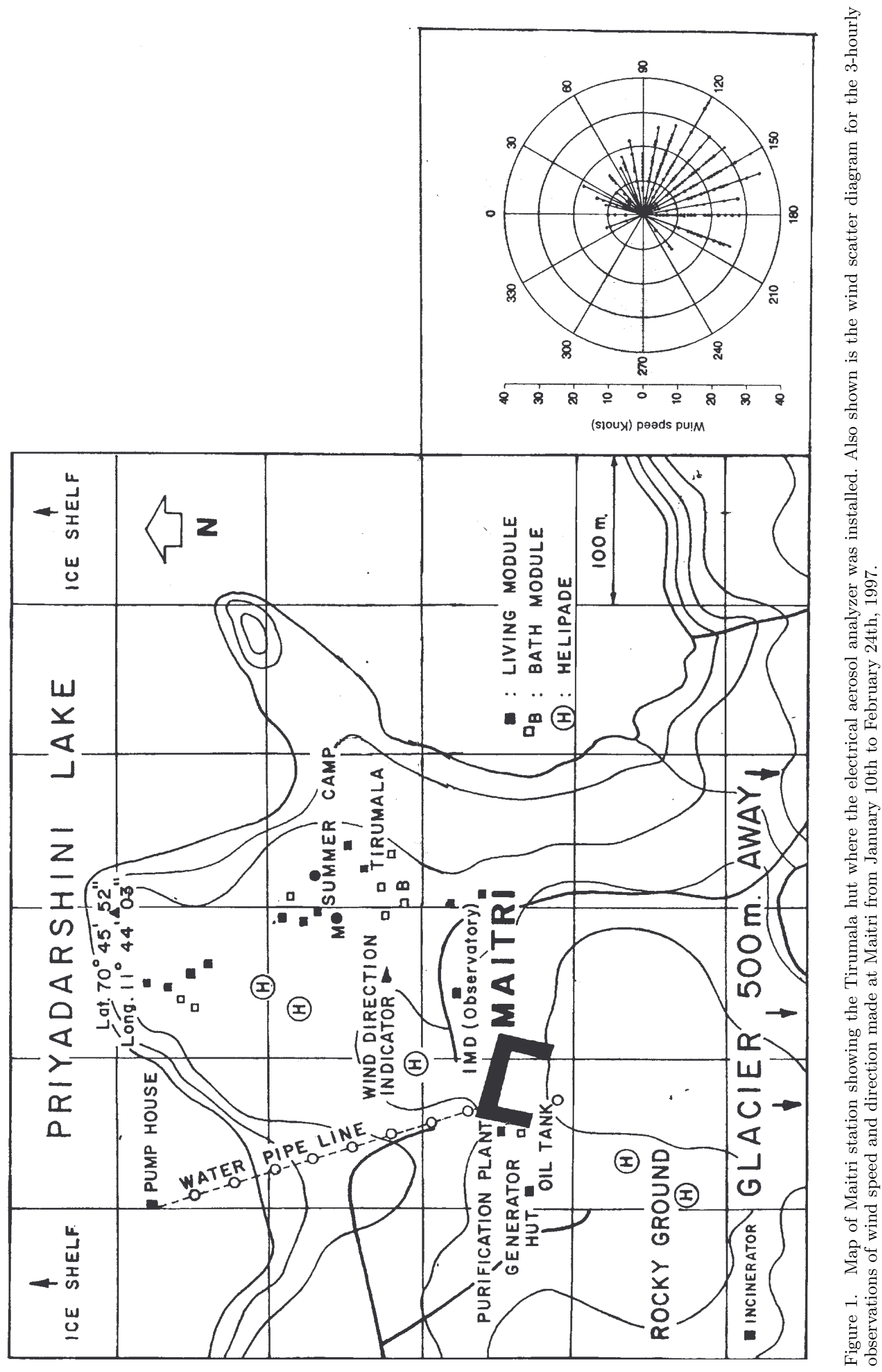



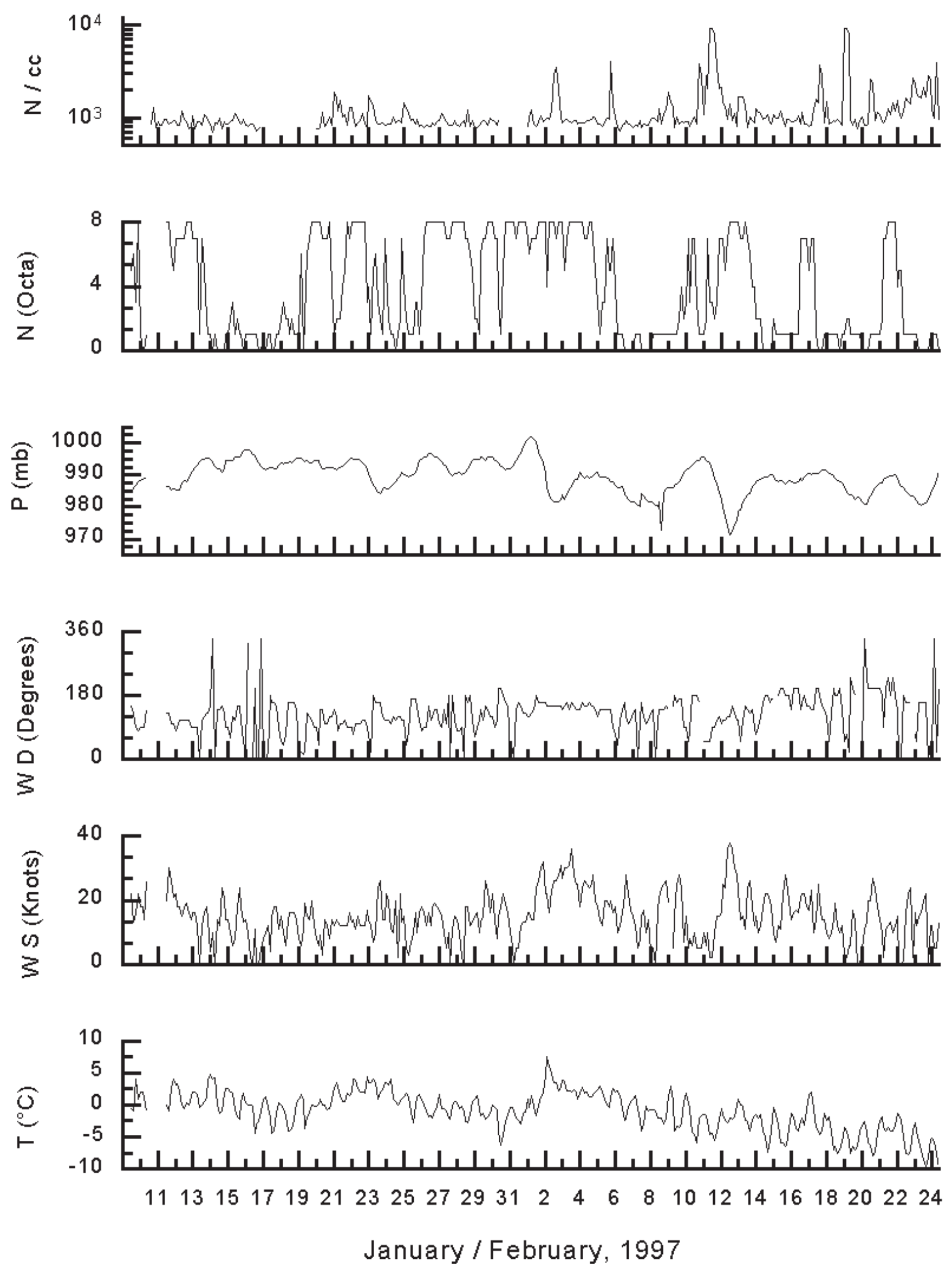

Figure 2. The variation of meteorological parameters namely temperature $(T)$, wind speed $(W S)$, wind direction $(W D)$, atmospheric pressure $(P)$, total cloud coverage $(N)$ and the total aerosol concentration at Maitri from January 10 th to February 24th, 1997. 


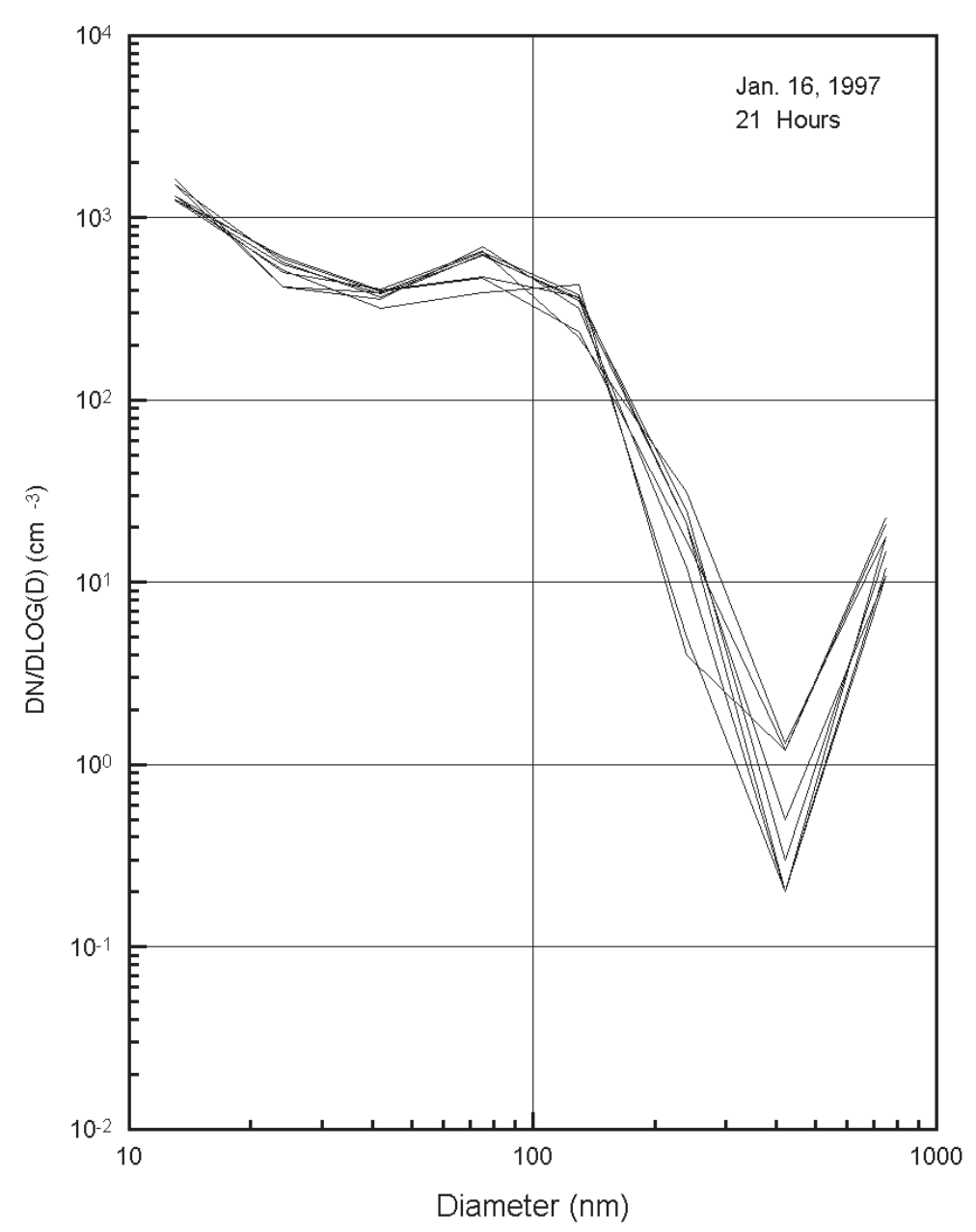

Figure 3. Typical aerosol size-distribution curves on a fair weather day, January 16th, 1997, at Maitri.

Jaenicke et al (1992) at Georg-von-Neumayer $\left(72^{\circ} 37^{\prime} \mathrm{S}, 8^{\circ} 22^{\prime} \mathrm{W}\right)$, and by Ito (1993) at Syowa $\left(69^{\circ} \mathrm{S}, 39.6^{\circ} \mathrm{E}\right)$. Earlier measurements at Maitri by Lal and Kapoor (1989) also show similar concentrations of Aitken nuclei in the months of January and February. The measurements of Voskresenskii (1968) at Mirny $\left(66.6^{\circ} \mathrm{S}, 93^{\circ} \mathrm{E}\right)$, however, show condensation nuclei concentrations of only up to a few hundreds of particles $\mathrm{cm}^{-3}$. Most of these observers report a decrease in nuclei concentration by an order or two in winter months. Gras and Adriaansen (1985) measured condensation nuclei concentration at Mawson during 1981-84 and showed that the diurnal variation of Aitken nuclei particles is generally weak (less than $10 \%$ of the mean) and not well organised with respect to the time of the day or season. Jaenicke et al (1992) reported that the data at Georg-von-Neumayer, a coastal station, is well correlated with that at the South Pole station, Amundsen-Scott, indicating some common history of the particles. Further, they report a constant increase of $9.63 \%$ per year in the average concentration at this station from 1982 to 1990. Observations of such a dramatic increase in aerosol concentration at their station calls for a constant monitoring or at least periodic checking of the aerosols.

Total aerosol concentrations are found to be smaller in the month of January than in February. Moreover, some peaks of very high aerosol concentrations are observed in the month of February. Such peaks in aerosol concentrations have also been observed at other Antarctic coastal stations such as Mirny (Voskresenskii 1968), Siple (Hogan 1975), Syowa (Ito 1980), Georg-von-Neumayer (Jaenicke et al 1992), and even at the South Pole (Hogan 1979). These peaks are mostly associated with the passage of cyclonic storms circulating around the continent of Antarctica. The 3-hourly observations of surface pressure and cloudiness made at Maitri support such an association.

\section{Size distribution of aerosols at Maitri}

A total of 1620 size distributions were measured during this period at Maitri. In general, size distributions are trimodal and remain almost unchanged for several hours or days provided there is no substantial change in the meteorological conditions at 


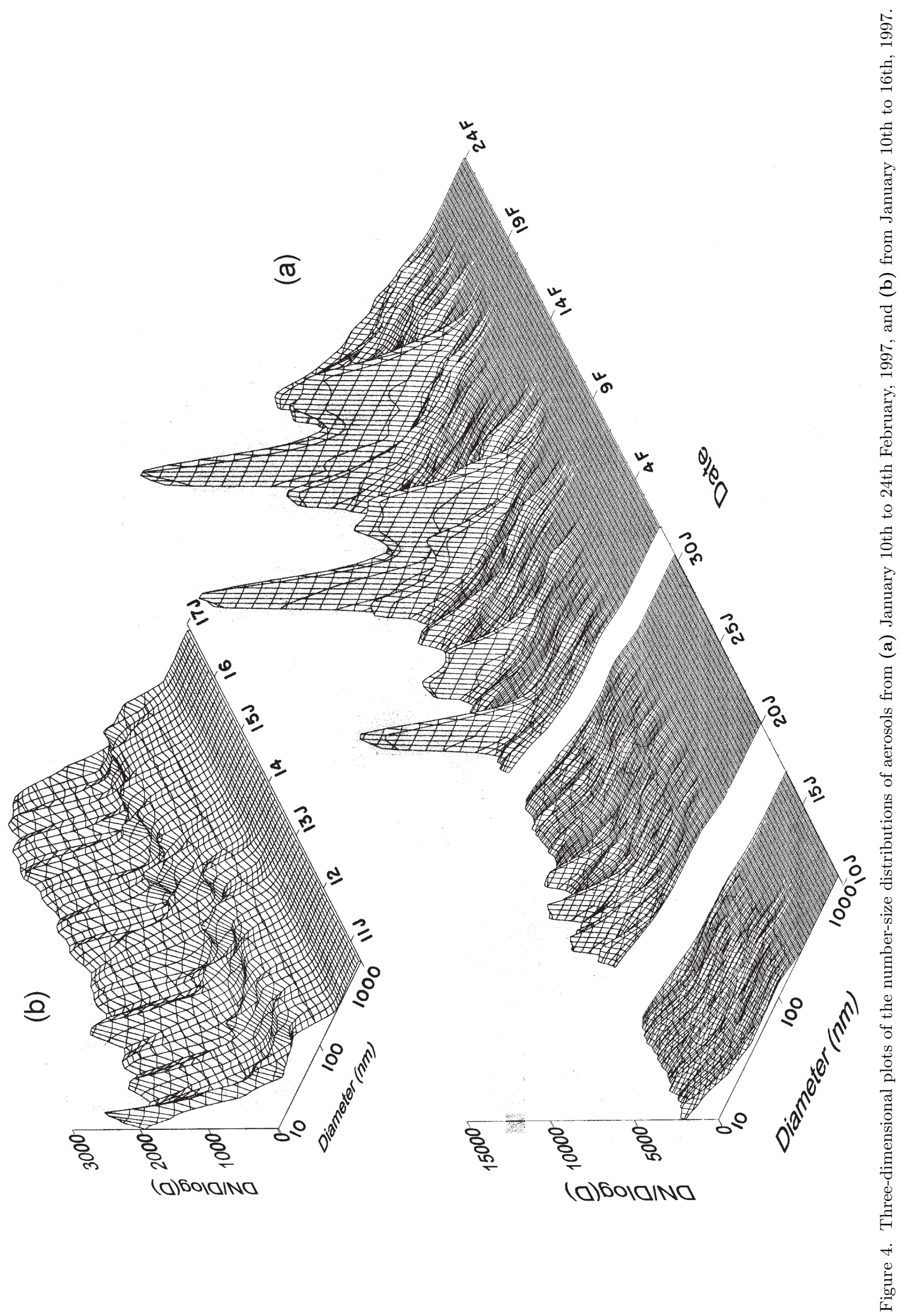



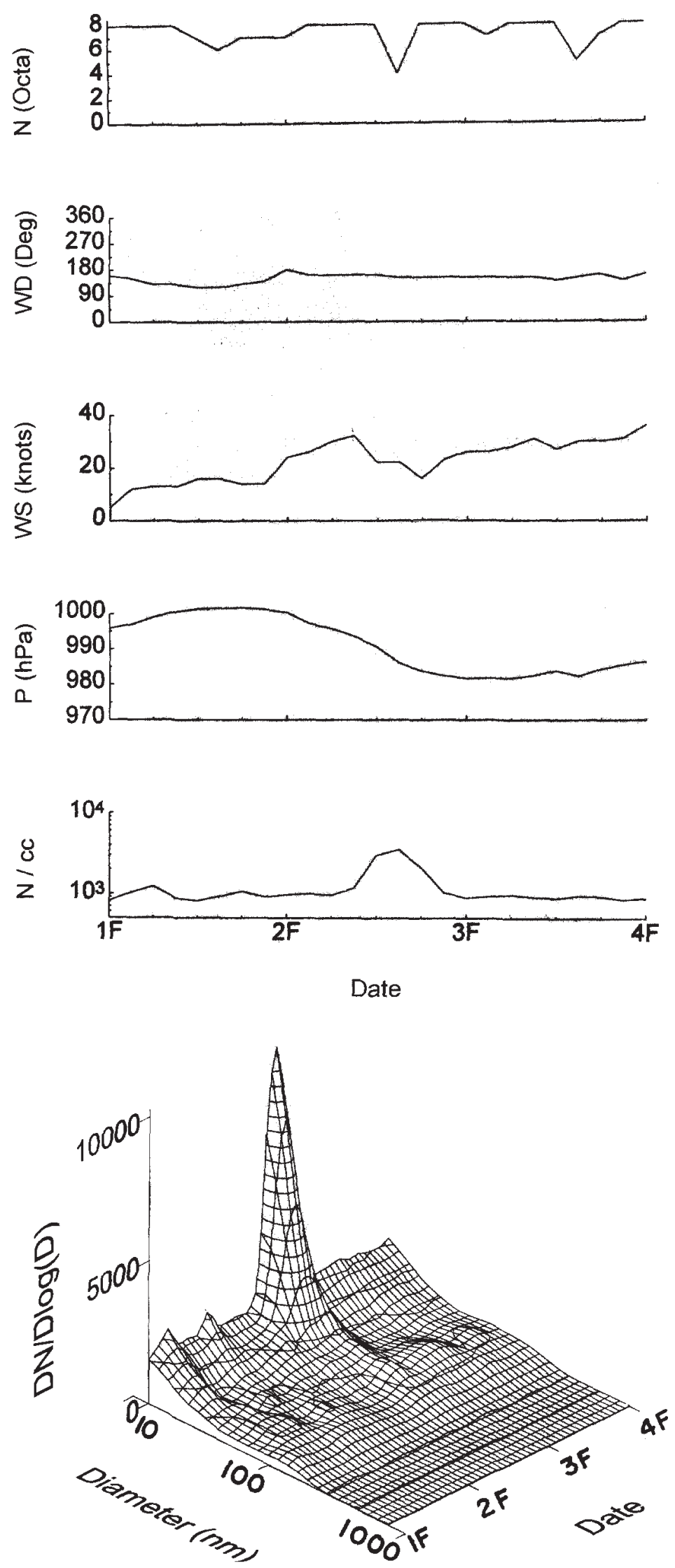

Figure 5. The total aerosol concentration and three-dimensional plot of number-size distribution of aerosols alongwith the surface atmospheric pressure, wind speed, wind direction and cloud coverage during the passage of a low pressure system over Maitri during February 1st-4th, 1997. 


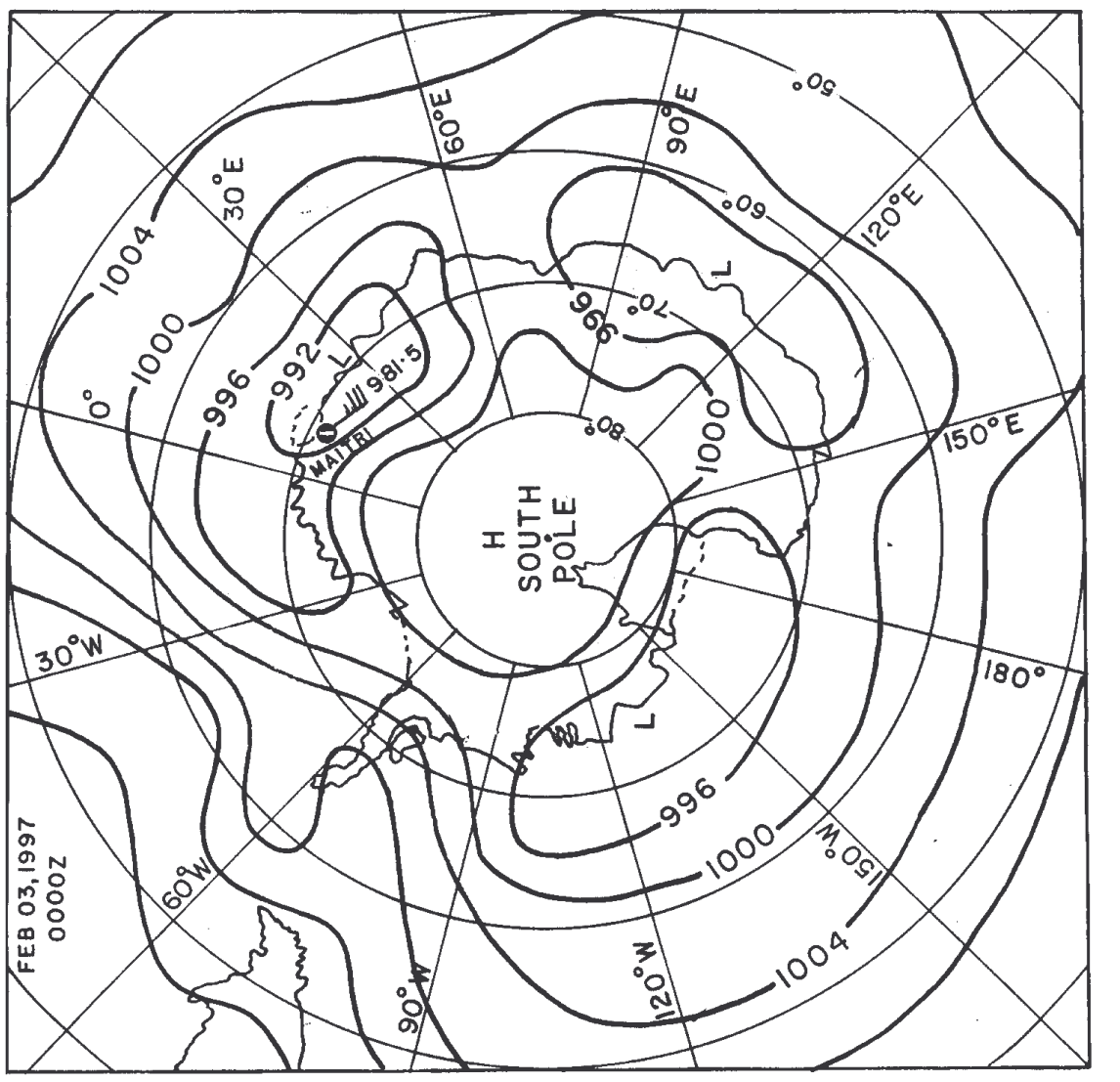

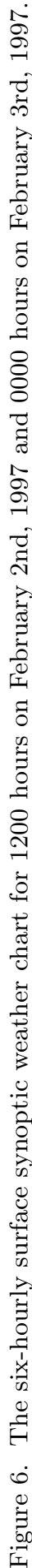

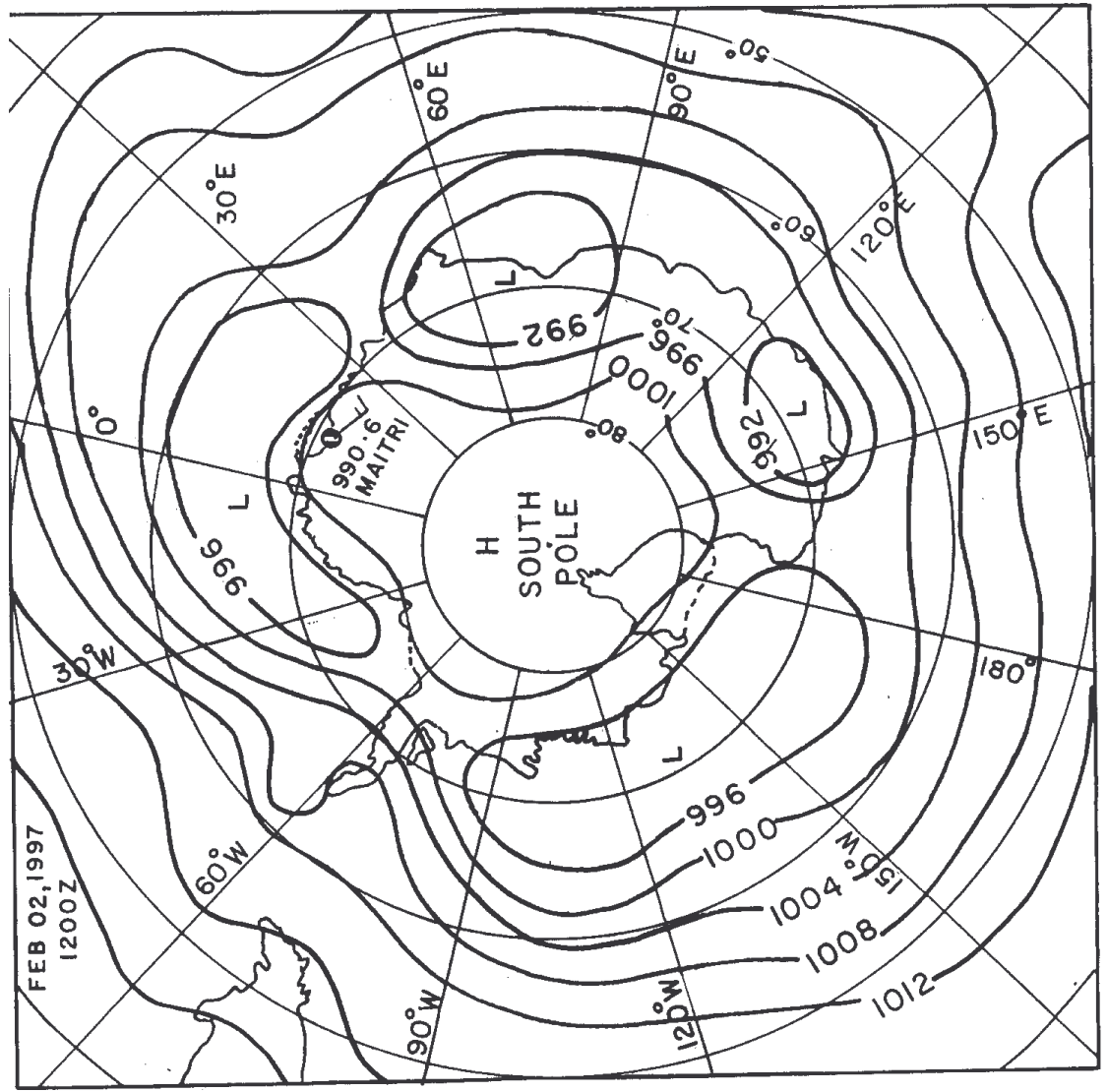



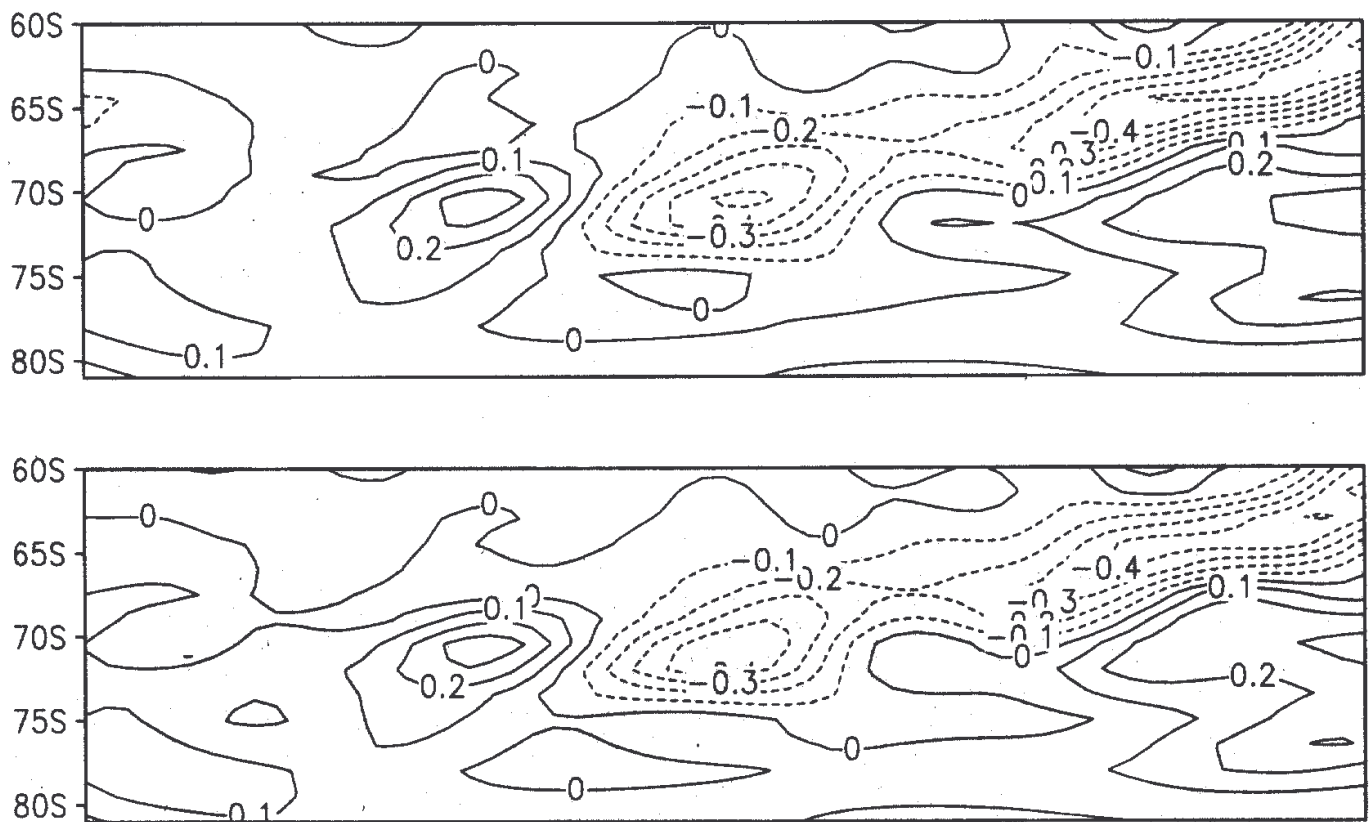

$1250 \mathrm{~m}$
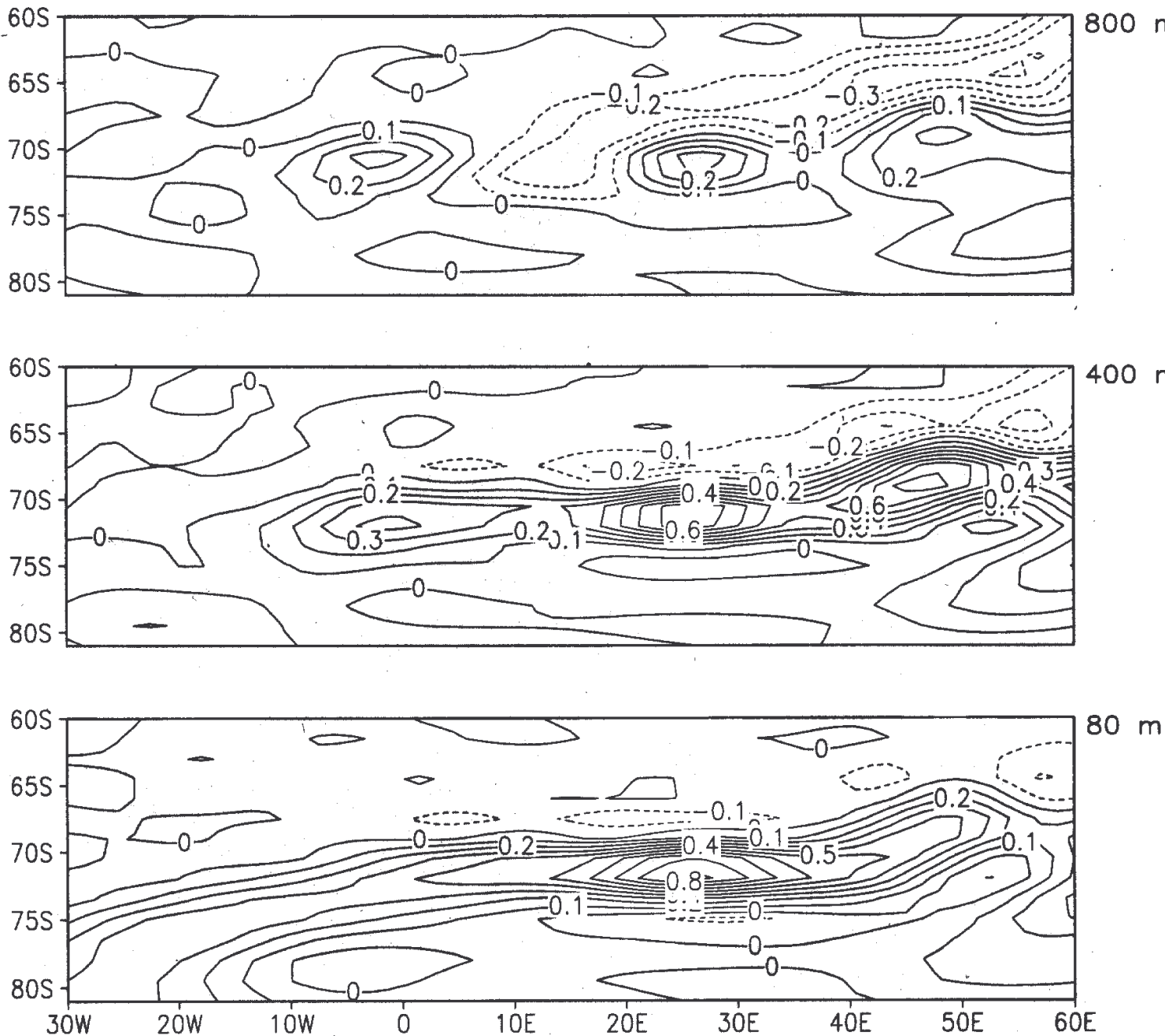

Figure 7. The vertical velocity analysis at 70, 400, 800, 1200 and 1700 levels at 1100 GMT on February 2nd, 1997. The vertical velocity data uses SI unit of Pascal per second. Continuous contours show upward and dotted contours downward velocities. 
Backward trajectory ending at 06 UTC 02 Feb 97 CDC1 Meteorological Data

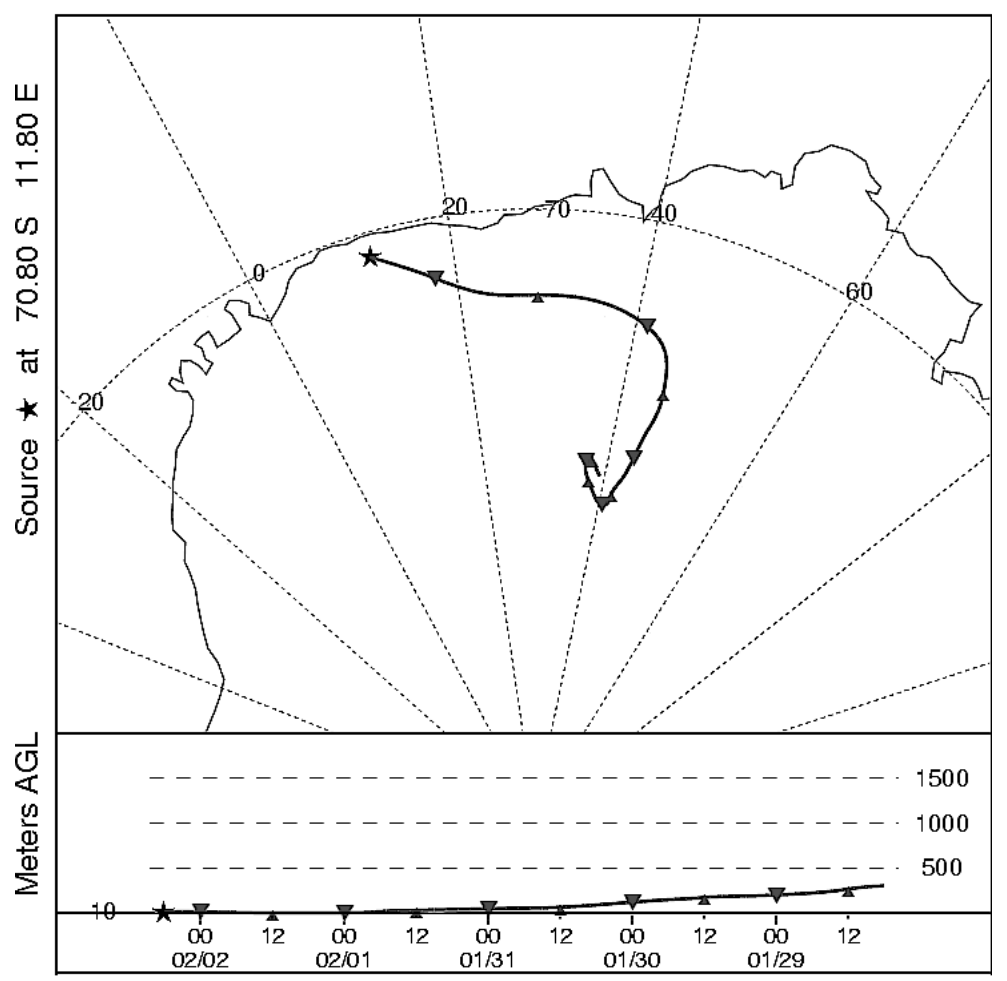

Backward trajectory ending at 15 UTC 02 Feb 97 CDC1 Meteorological Data

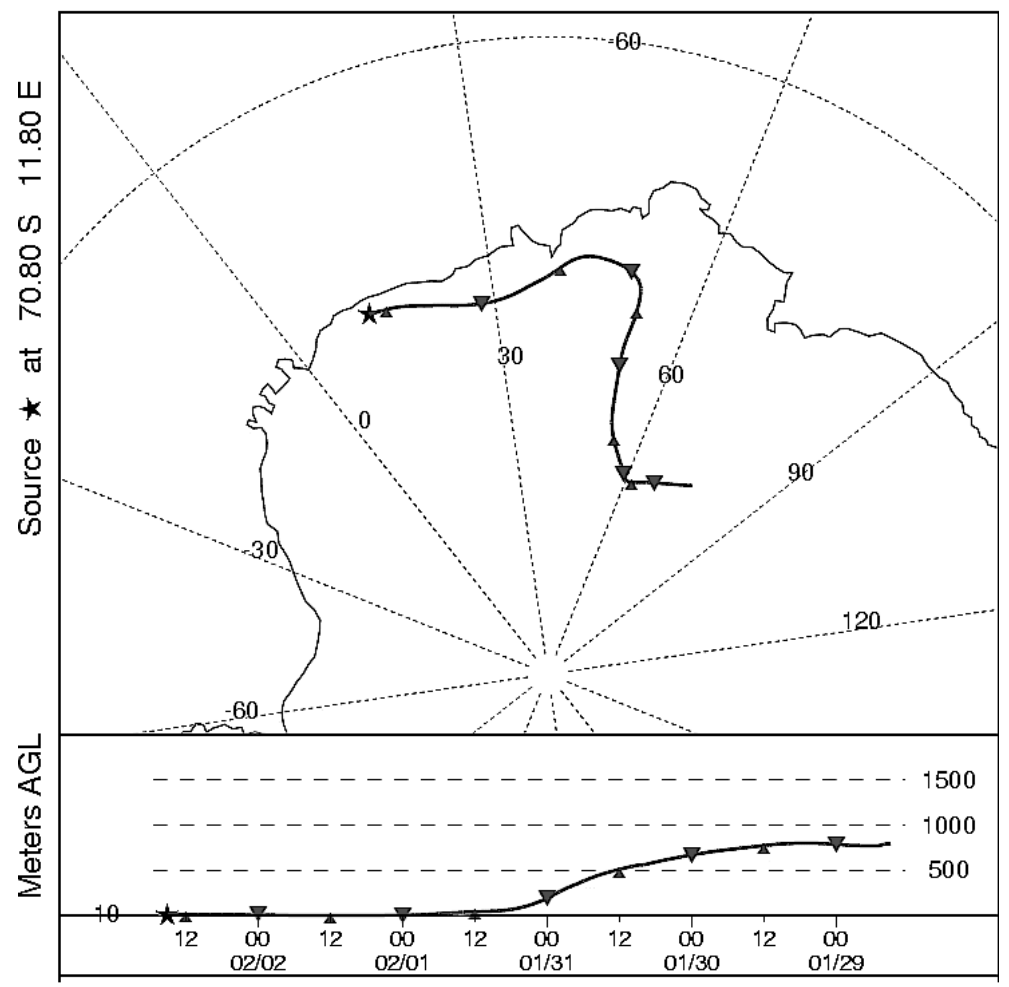

Figure 8. (Continued) 


\section{Backward trajectory ending at 03 UTC 03 Feb 97} CDC1 Meteorological Data

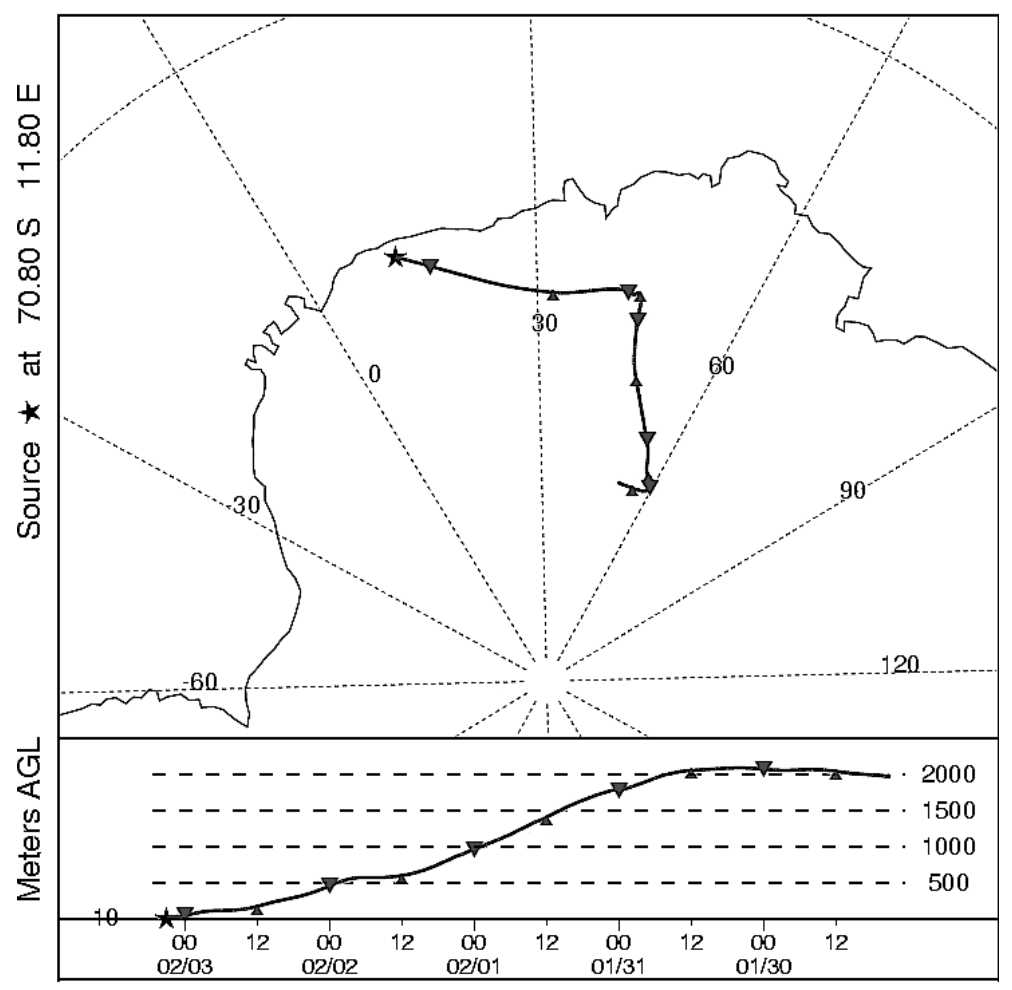

Figure 8. The 5-day back trajectories at 0600 and 1500 GMT on February 2nd, 1997 and at 0300 GMT on February 3rd, 1997 at Maitri.

the station. There is no typical diurnal pattern in the size distribution or concentration of aerosols. All size distributions are trimodal with a peak either at $75 \mathrm{~nm}$ or $133 \mathrm{~nm}$ diameter and two minima at 42 and $420 \mathrm{~nm}$ and are open-ended at both ends. For example, figure 3 shows the size distributions for January 16th, 1997 which is a typical fair-weather day without any low pressure system or high wind conditions over the station. The mode at $75 \mathrm{~nm}$ is the Aitken or fine mode. The concentration of particles larger than this continues to decrease with size except in the last stage i.e., $750 \mathrm{~nm}$ where the concentration shows a significant increase. An increase of more than an order of magnitude in this range cannot be assigned to instrumental error and should not be ignored because of its frequent appearance in our measurements and its indication to another mode of micron size. This micron mode may be expected to result from seasalt but then a sub-micron mode is also expected to appear in the data. There is clear absence of an accumulation mode or a cloud residual mode assuming that the accumulation mode forms from cloud processing of Aitken mode particles (Hoppel et al 1986 and 1994). Earlier observations at Syowa station also show a peak at about $60 \mathrm{~nm}$ radius in December in the size-range common in the measurements of ours and those of Ito (1993). Ito (1983,
1985) reports bimodal size distribution with persistent modes at $6 \mathrm{~nm}$ and $60 \mathrm{~nm}$ radius at Syowa station. Radke and Lyons (1982) also observe a maximum at about $80 \mathrm{~nm}$ at Ross sea. At Ross sea, Harvey et al (1991) does observe maximum concentrations at about $100 \mathrm{~nm}$ with increasing trend of concentration for smaller particles but they do not observe a minimum in size distribution at $420 \mathrm{~nm}$ such as the one observed at Maitri. Jaenicke's observations also show that the average particle diameter peaks in the $30-70 \mathrm{~nm}$ range in summer. However, he found that $45 \%$ of all distribution shapes in summer are multimodal with maxima at 10 and $65 \mathrm{~nm}$ diameters. The maximum on larger size in these observations certainly agrees with our observations. Although, the smaller size maximum is not covered in our measured size-range, very high concentrations of $10^{3}-10^{4}$ particles $/ \mathrm{cm}^{3}$ of smaller particles in $3-7 \mathrm{~nm}$ size-range do indicate a maximum for particles smaller than $13 \mathrm{~nm}$.

Figure 4(a) shows a three-dimensional view of the aerosol size distributions observed during January 11th to February 24th, 1997 at Maitri. The trimodal size distributions of aerosols and the changing positions of second peak between 75 and $133 \mathrm{~nm}$ diameter are well illustrated here. The appearance of peaks in the nucleation mode of aerosol size-distributions associated with low 
(a)
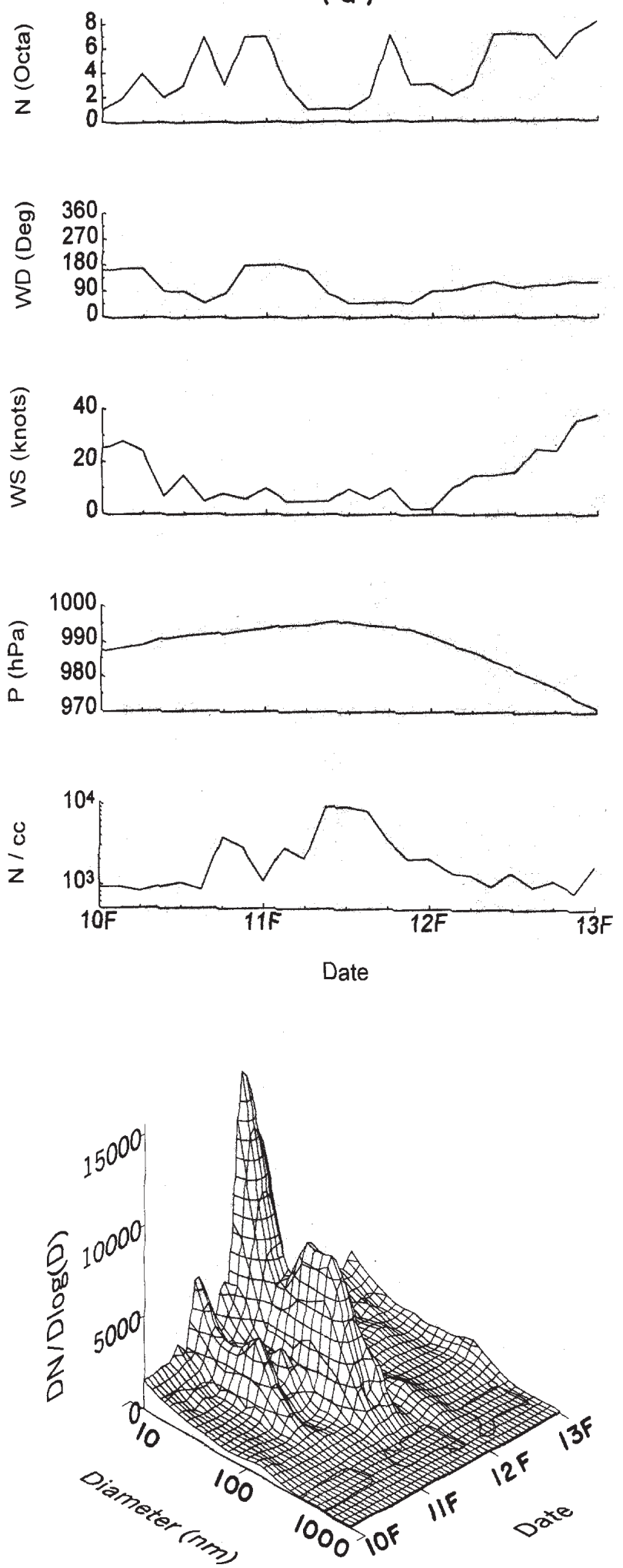

(b)
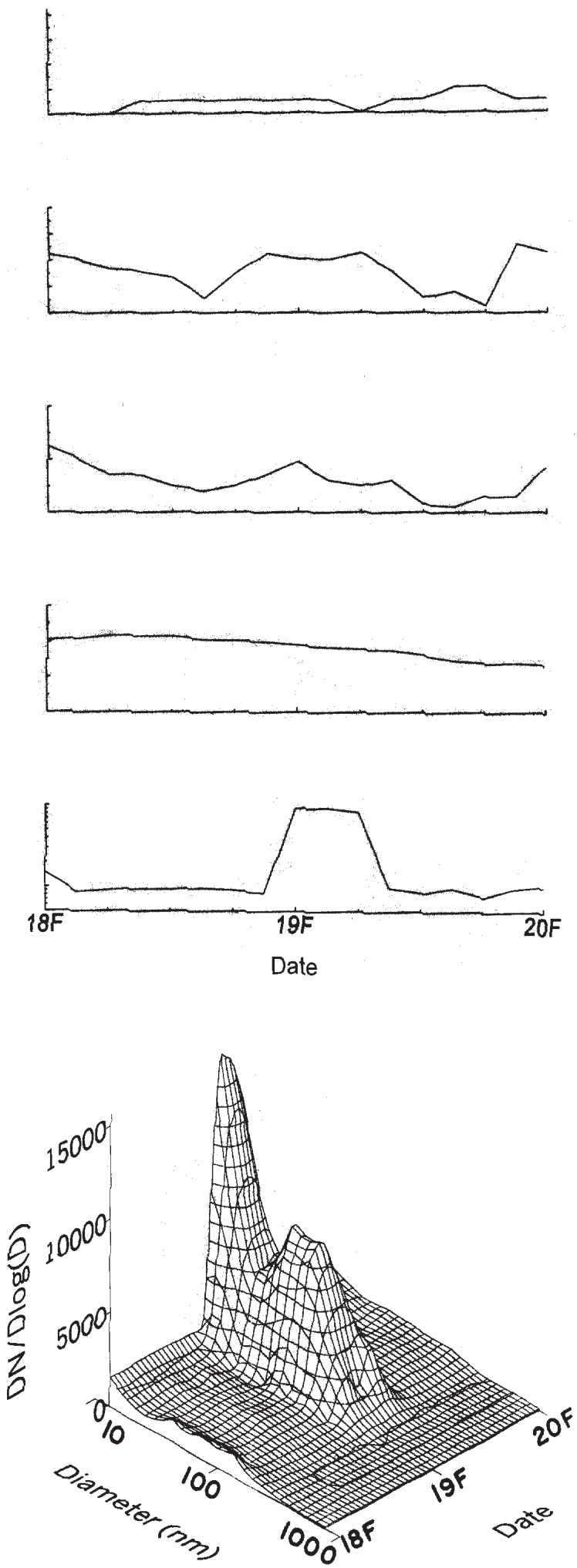

Figure 9. As in figure 6, during (a) February 10th-14th, 1997 and (b) February 18th-20th, 1997. 
Table 1. Average modal parameters for the measurements made at Maitri, Antarctica during January-February $199 \%$.

\begin{tabular}{lccc}
\hline Particulars & $\begin{array}{c}\text { Modal } \\
\text { parameters }\end{array}$ & $\begin{array}{c}\text { Aitken } \\
\text { number }\end{array}$ & $\begin{array}{c}\text { Accumulation } \\
\text { number }^{2}\end{array}$ \\
\hline Background aerosol & $N$ & $427 \pm 133$ & $107 \pm 39$ \\
average & $D_{g} N$ & $67.3 \pm 18$ & $153.2 \pm 42$ \\
& $\sigma$ & $1.687 \pm 0.007$ & $1.706 \pm 0.003$ \\
\hline Case 1 & $N$ & $750 \pm 148$ & $95 \pm 25$ \\
& $D_{g} N$ & $59.8 \pm 10$ & $175 \pm 19$ \\
& $\sigma$ & $1.694 \pm 0.002$ & $1.706 \pm 0.001$ \\
\hline Case 2 & $N$ & $3239 \pm 1952$ & $419 \pm 337$ \\
& $D_{g} N$ & $55.5 \pm 19$ & $242 \pm 38$ \\
& $\sigma$ & $1.682 \pm 0.007$ & $1.706 \pm 0.001$ \\
\hline Case 3 & $N$ & $616 \pm 142$ & $423 \pm 100$ \\
& $D_{g} N$ & $55.9 \pm 7.6$ & $278.1 \pm 40$ \\
& $\sigma$ & $1.684 \pm 0.004$ & $1.703 \pm 0.001$ \\
\hline
\end{tabular}

$1 \mathrm{~N}\left(\mathrm{~cm}^{-3}\right), \mathrm{D}$ (geometric in $\left.\mathrm{nm}\right), \sigma$ (standard deviation of the size distribution).

2 Modal parameters are calculated from log normal fits to the size distribution.

\pm refers to the atmospheric variability.

pressure episodes and the rapid restoration of size distributions to their normal shapes before and after the peaks can be clearly seen in this diagram. The changing positions of the accumulation mode in otherwise almost uniform size distributions observed continuously for six fair-weather days from January 10th-16th, 1997 is noticeable in figure 4(b). Modal parameters for the background aerosol size distributions averaged for the whole period at Maitri except for the periods of peaks are shown in table 1. Number concentrations in Aitken mode are approximately four times that in accumulation mode and the particles in Aitken mode are relatively quite aged.

\section{Changes in the aerosol concentration and size distribution associated with the changes in meteorological conditions at Maitri}

The 'wall of storms' formed by polar lows circulating around the Antarctica Convergence Zone makes a strong barrier for aerosol transport. Under the influence of depressions moving eastsoutheastward between latitudes $65^{\circ}$ and $70^{\circ} \mathrm{S}$, the low pressure systems sometimes penetrate up to some coastal stations. Maitri experienced a sequence of rise and fall in surface pressure during this period. A dip in surface pressure during this period at the station is most of the time preceded by several hours by a peak in aerosol concentration. The aerosol size-distributions observed during the enhancement events in February, show different degrees of ageing. Below, we shall discuss the meteorological features associated with some events by using 3-hourly meteorological observations made at
Maitri, synoptic charts, and the vertical velocity analysis.

\subsection{Case 1}

Peak in aerosol concentration on 2nd-3rd February occurs while the surface pressure at Maitri, is falling from $1002 \mathrm{mb}$ to $982 \mathrm{mb}$ (figure 5). Southeasterly winds of 8 to $15 \mathrm{~m} \mathrm{~s}^{-1}$ with almost no change in direction, flow during this period. Enhancement in aerosol concentration starts as the cloud coverage starts decreasing in an overcast sky and the peak in aerosol concentration coincides with a dip in cloud cover. A low pressure system which was located southeast of Maitri at 1200 hours on February 2nd, 1997 moves over Maitri on February 3rd, 1997 accompanied with the strong southeasterly winds (figure 6). At the time of the peak in total aerosol concentration at 1500 hours of February 2nd, 1997, Maitri is located in front of the low pressure system approaching from the southeast. Figure 5 also illustrates the evolution of aerosol size-spectra during this period. The occurrence of peak in Aitken mode with almost no accumulation mode is indicative of these particles being freshly formed. Number concentration of Aitken mode particles is approximately 8 times of that in accumulation mode (table 1). The low pressure systems may bring in more marine air from the icemelt regions where DMS emissions are high, possibly leading to photochemical production of new particles locally when the cloud cover decreases. These small particles may also be transported from the free troposphere into the boundary layer under mesoscale subsidence ahead of low pressure systems. The vertical velocity analysis at 1100 GMT on February 2nd, 1997 for the Antarctic region from 

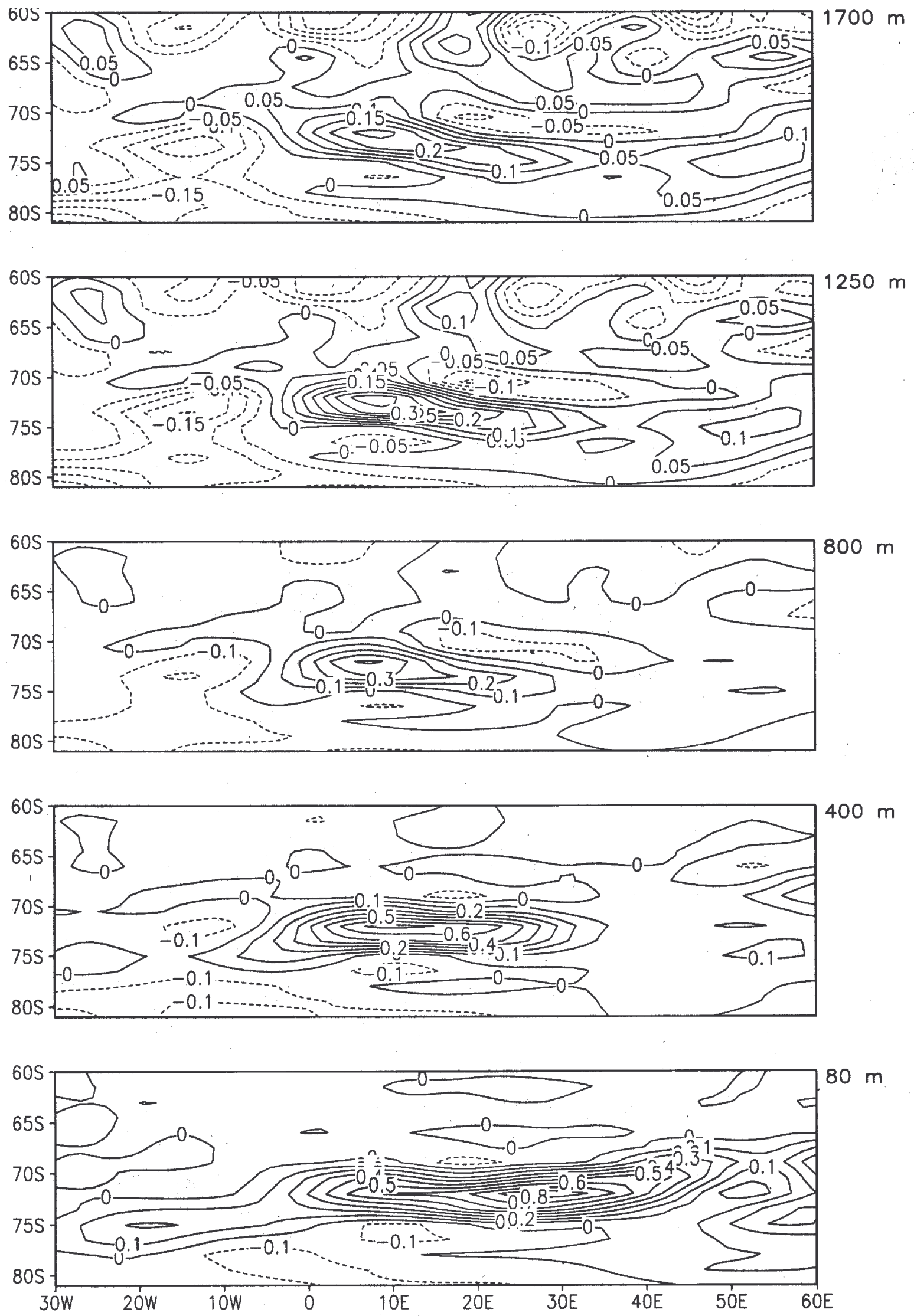

Figure 10. As in figure 7 at 2300 GMT on February 18th, 1997. 
Backward trajectory ending at 12 UTC 10 Feb 97 CDC1 Meteorological Data

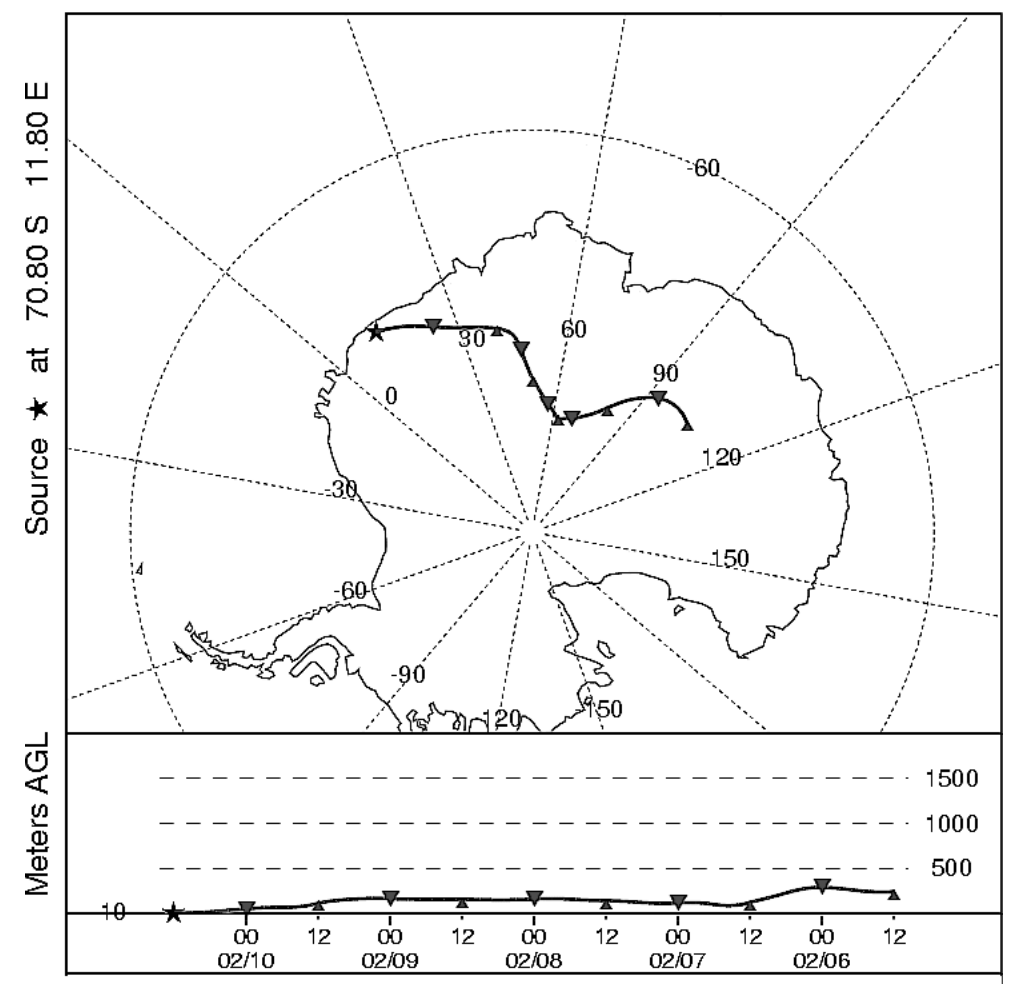

Backward trajectory ending at 12 UTC 11 Feb 97 CDC1 Meteorological Data

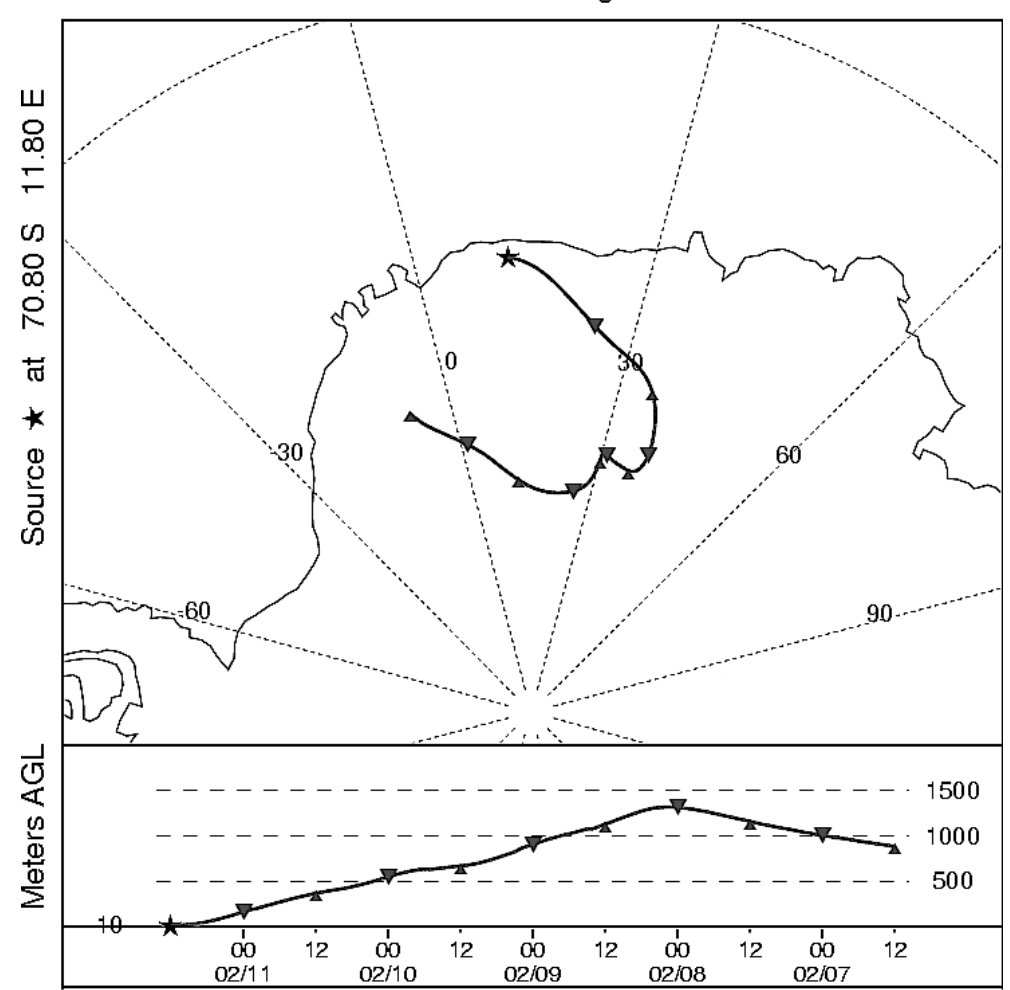

Figure 11(a). (Continued) 
Backward trajectory ending at 12 UTC 12 Feb 97 CDC1 Meteorological Data

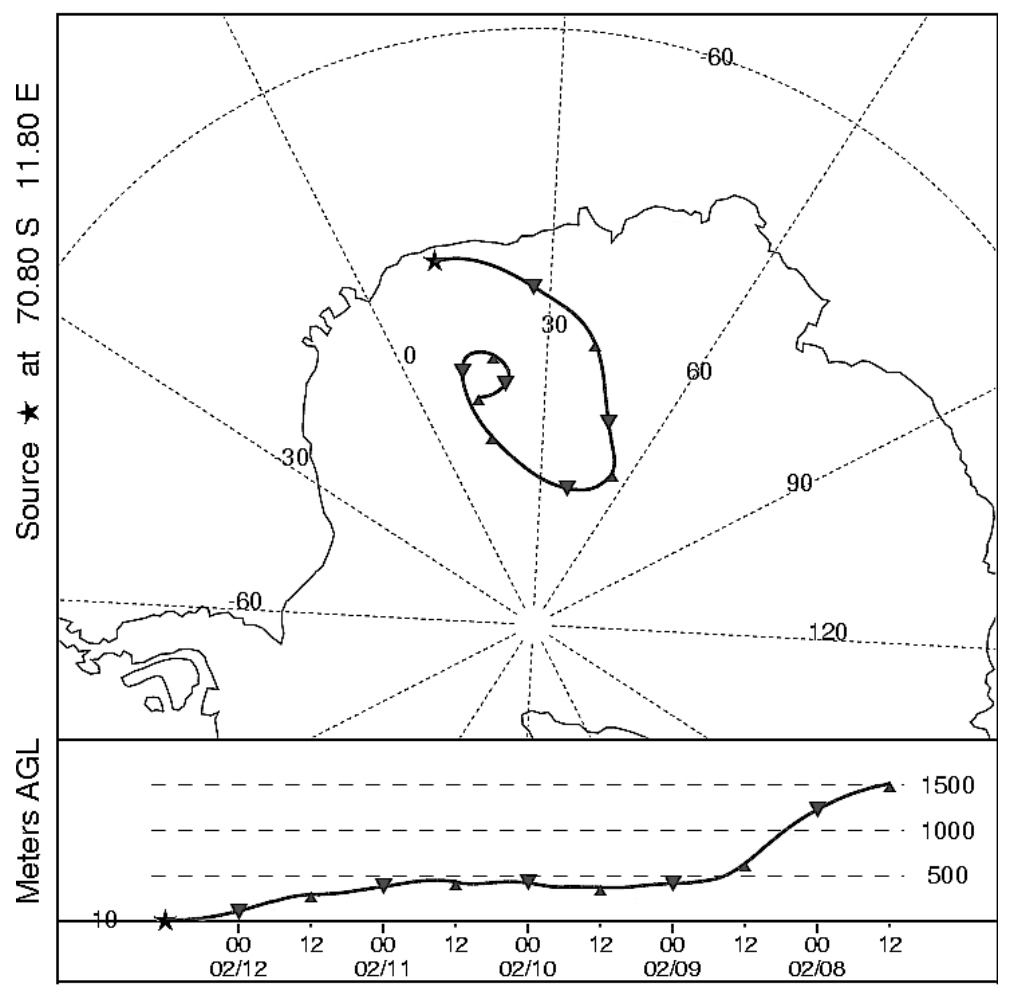

Figure 11(a). The 5-day back trajectories at 1200 GMT on February 10th, 11th and 12th, 1997 at Maitri.

Backward trajectory ending at 15 UTC 18 Feb 97 CDC1 Meteorological Data

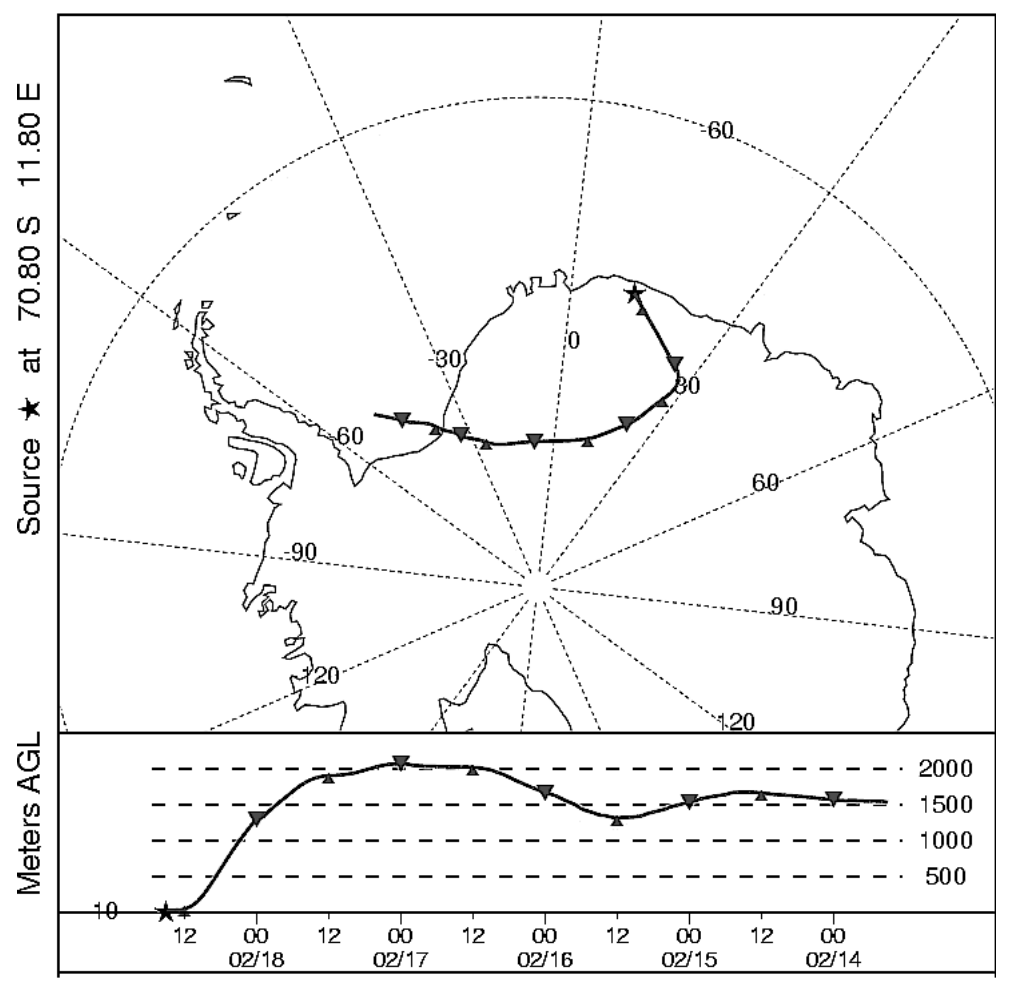

Figure 11(b). (Continued) 


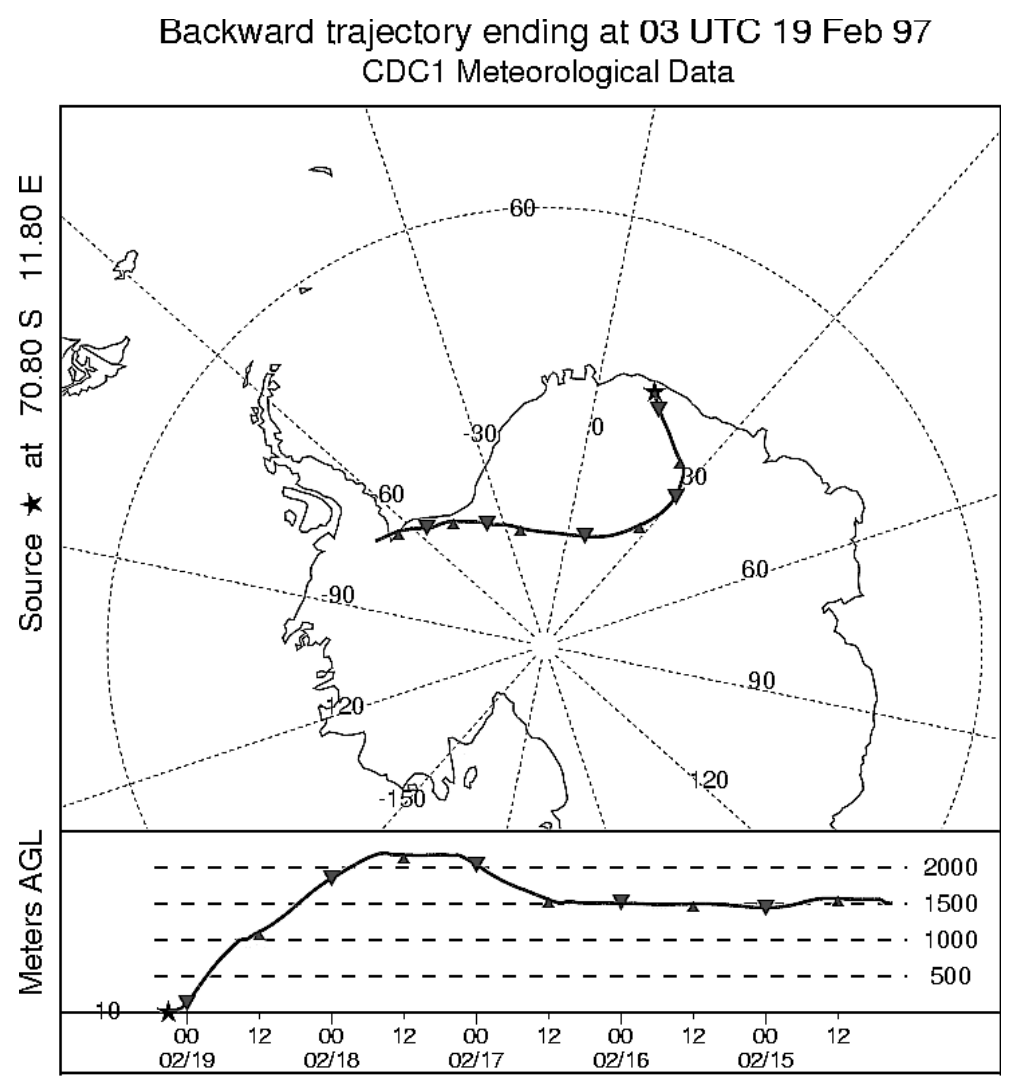

Backward trajectory ending at 15 UTC 19 Feb 97 CDC1 Meteorological Data

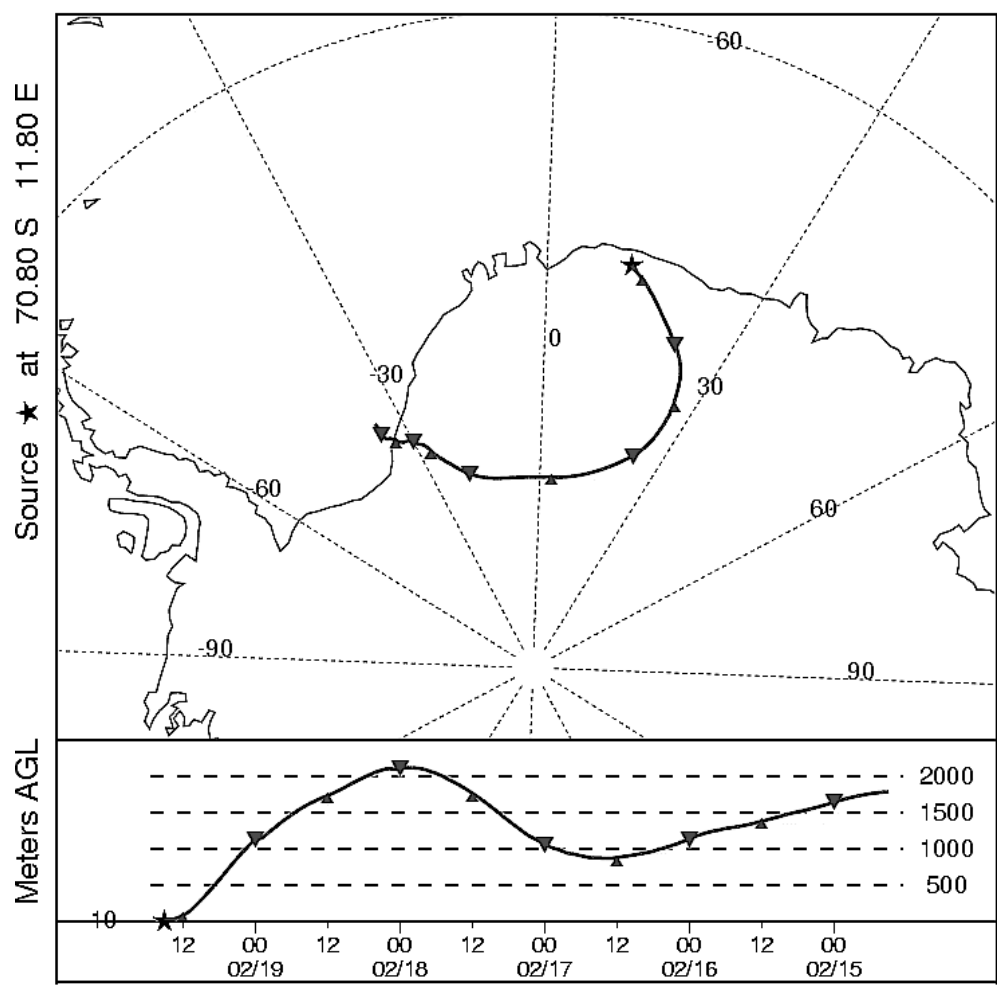

Figure 11(b). The 5-day back trajectories at 1500 GMT on February 18th, 0300 GMT and 1500 GMT on February 19th, 1997 at Maitri. 
GASP model of Australian Bureau of Meteorology (Bourke et al 1995, 1999) which gives the vertical velocities with a latitude longitude resolution of $1.5 \times 1.5$ degrees, shows subsidence near Maitri (figure 7). The 5-day backward trajectory analysis (Draxler and Rolph 2003; Rolph 2003) in figure 8 shows that the source of air parcel remains almost the same from February 2nd to 4th, 1997. However, at the time of the maximum in aerosol concentration, the trajectory shifts and the air parcel travels close to surface during the last $2-3$ days. The air parcel having such a trajectory is likely to pick up more DMS from the ice-melt regions at the surface.

\subsection{Case 2}

In this case, aerosol size distribution become bimodal with maxima at $<13$ and at $75 \mathrm{~nm}$ during the enhancement period (figures 9a, b). The enhancement events on both days are associated with almost clear skies. Wind speeds are comparatively low and their directions change drastically during these periods. Although a frequency of 3hourly observations of winds is not sufficient to precisely examine the relation of the changes in wind speed with the aerosol enhancement, the available data indicate that the aerosol enhancement on February 11th is associated with the change from southerly to northeasterly winds and on February 19th with the change of the northeasterly to southerly winds. The nucleation mode during such enhancement periods may be due to photochemical production from DMS emissions brought by the marine air or the air from the ice-melt regions. Aitken mode may result as a consequence of condensational growth of these particles. Although the number of particles in both modes are very high, the ratio of particle concentration in Aitken and accumulation modes remains almost the same as in Case 1. Particles in Aitken mode have the shortest and in accumulation mode the largest age of all cases (table 1). Synoptic charts and vertical velocity analysis show that at the time of maxima in aerosol concentration, Maitri is located under a subsidence region in front of a cyclonic storm. Figure 10 shows strong subsidence at Maitri at 2300 GMT on February 18th, 1997. Similar case of subsidence is observed on February 11th, 1997. Nearly similar shapes of backward trajectories on February 11th and 19th, 1997, shown in figure 11, support that similar processes are responsible for the evolution of the aerosol size-distribution and justifies their inclusion in one category. Further, the downward transport of the air parcel during the last 2-3 days of such trajectories will not only transport more submicron particles from upper to lower levels but also encourage their growth by condensation.

\subsection{Case 3}

In this case also, aerosol size distribution is bimodal but the magnitude of the maximum in nucleation mode $(<13 \mathrm{~nm})$ is much reduced and the second maximum is shifted to the larger size $(133 \mathrm{~nm})$ (figure 12). This size distribution is observed when the station experiences the minimum of atmospheric pressure, and the winds are increasing but variable in direction. The aerosol in this case is more aged than that in Case 2 and the second maximum may result because of coagulation and cloud processes. The vertical velocity analysis shown for 23 GMT on February 12th, 1997 is shown in figure 13. Backward trajectories, shown in figure 14, show transport of the aerosols from long distances over coastal region. This will help aerosol particles grow by coagulation. Further, it also explains the longer age of the accumulation mode particles as compared to the age of particles in all other cases in table 1 .

\section{Discussion}

The transport, evolution and removal of aerosol particles or trace gases over Antarctica is mainly controlled by the atmospheric circulation patterns, which are affected by the geographic features of the high elevated ice sheet. The observations made at the coastal stations are more difficult to interpret than those at the higher polar plateau because of greater intermixing of the effects of strong continental drainage flows due to sloped inversions and katabatic winds, and the baroclinic disturbances generated over the southern ocean regions surrounding the Antarctica continent.

This time of year is the ice-melt time and melting ice is an excellent habitat for phytoplankton leading to very high DMS emissions. Davison et al (1996) observed that the maximum concentrations of up to $714 \mathrm{ng}(\mathrm{S}) \mathrm{m}^{-3}$ of DMS during their cruise from the U.K. to Antarctica are found in the vicinity of Antarctica Peninsula and in the Weddell Sea. On Schirmacher oasis, Maitri is exposed to the polar glacier ice-melting zone on the southern side and the ice-shelf melting zone on the northern side. Either of this ice-melting zone is $0.5-1 \mathrm{~km}$ away from Maitri. Further, in this season, shore is about $40-50 \mathrm{~km}$ north of Maitri. Beyond the shore, the fractional exposure of sea water increases with the distance from shore to the Antarctic circle. Priyadarshini lake, the only source of water for the Maitri station, is another source of phytoplankton especially where the seepage flows into it and supports profuse growth of algae. So, Maitri is expected to be well exposed to DMS emissions with prevailing winds from either direction. Active 

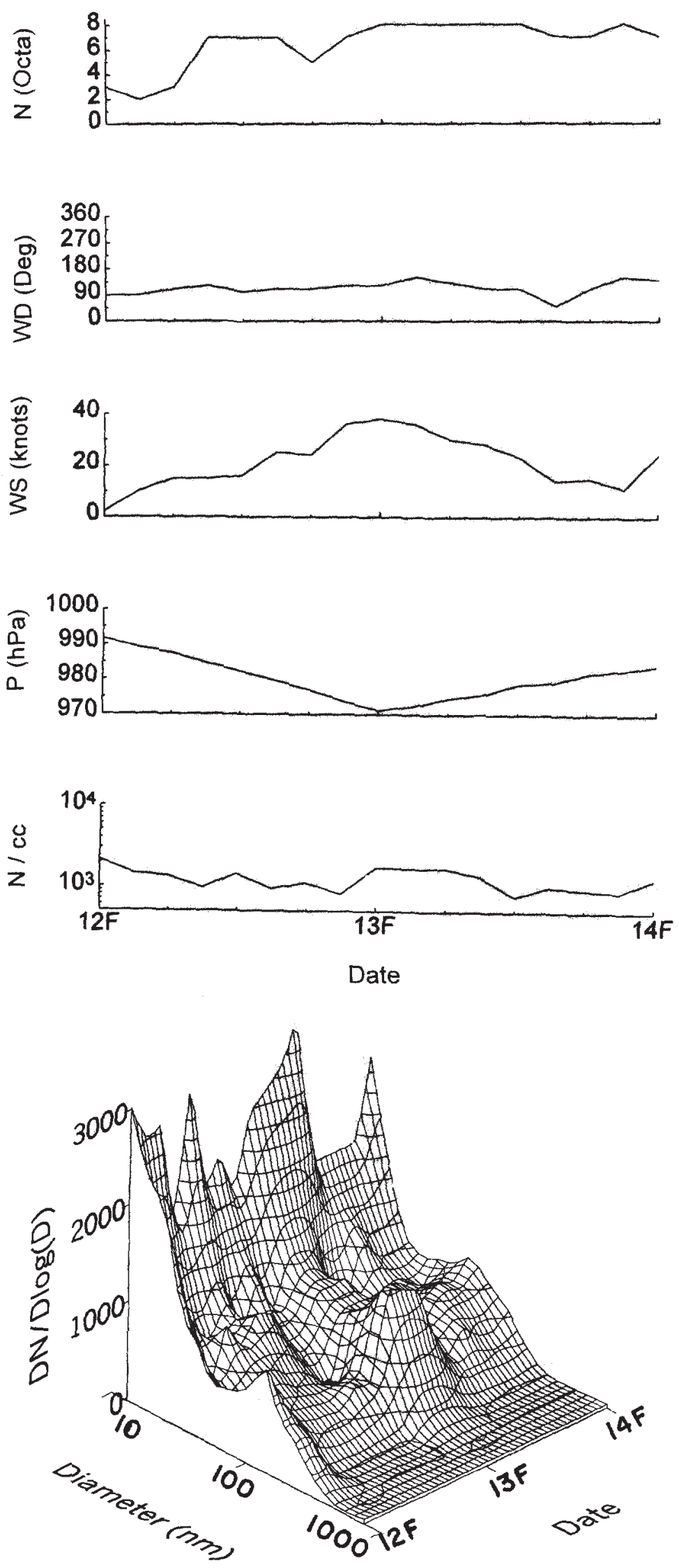

Figure 12. As in figure 6, during February 12th-14th, 1997. 


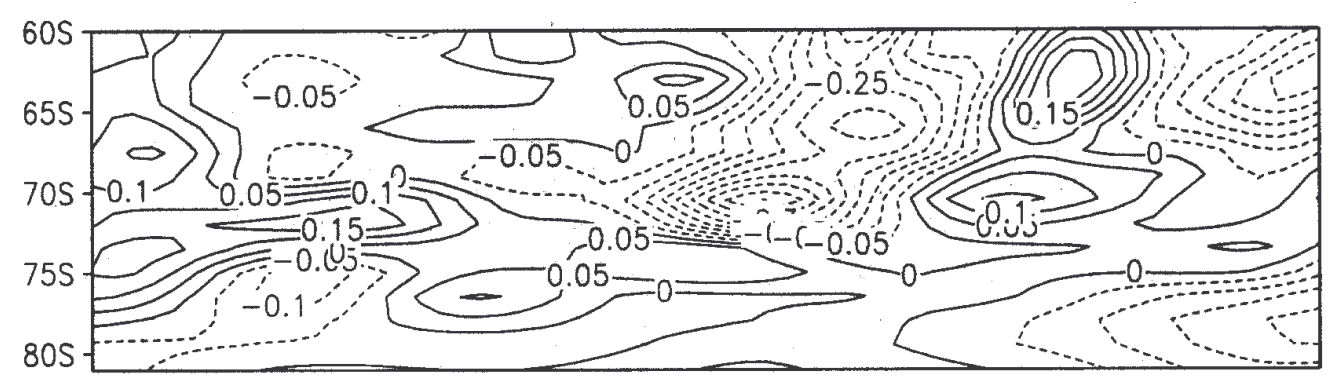

$1700 \mathrm{~m}$

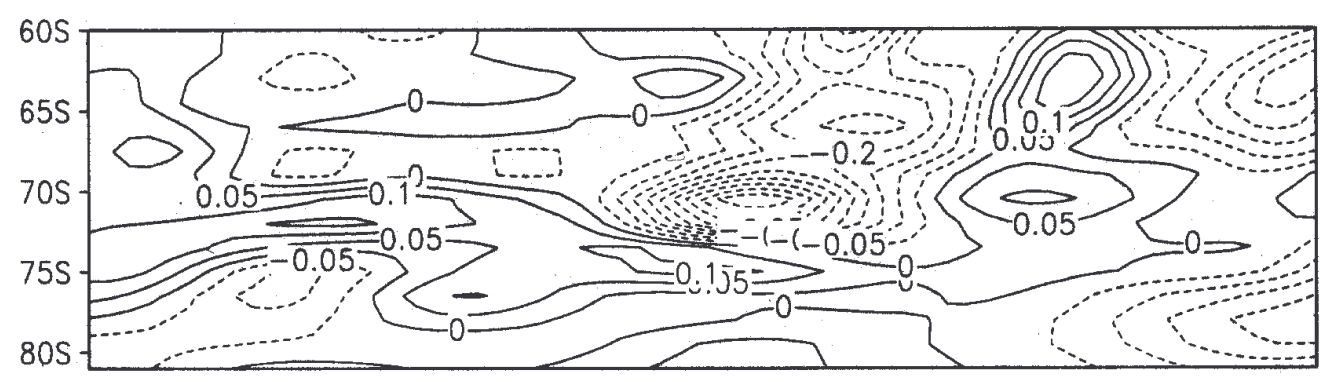

$1250 \mathrm{~m}$
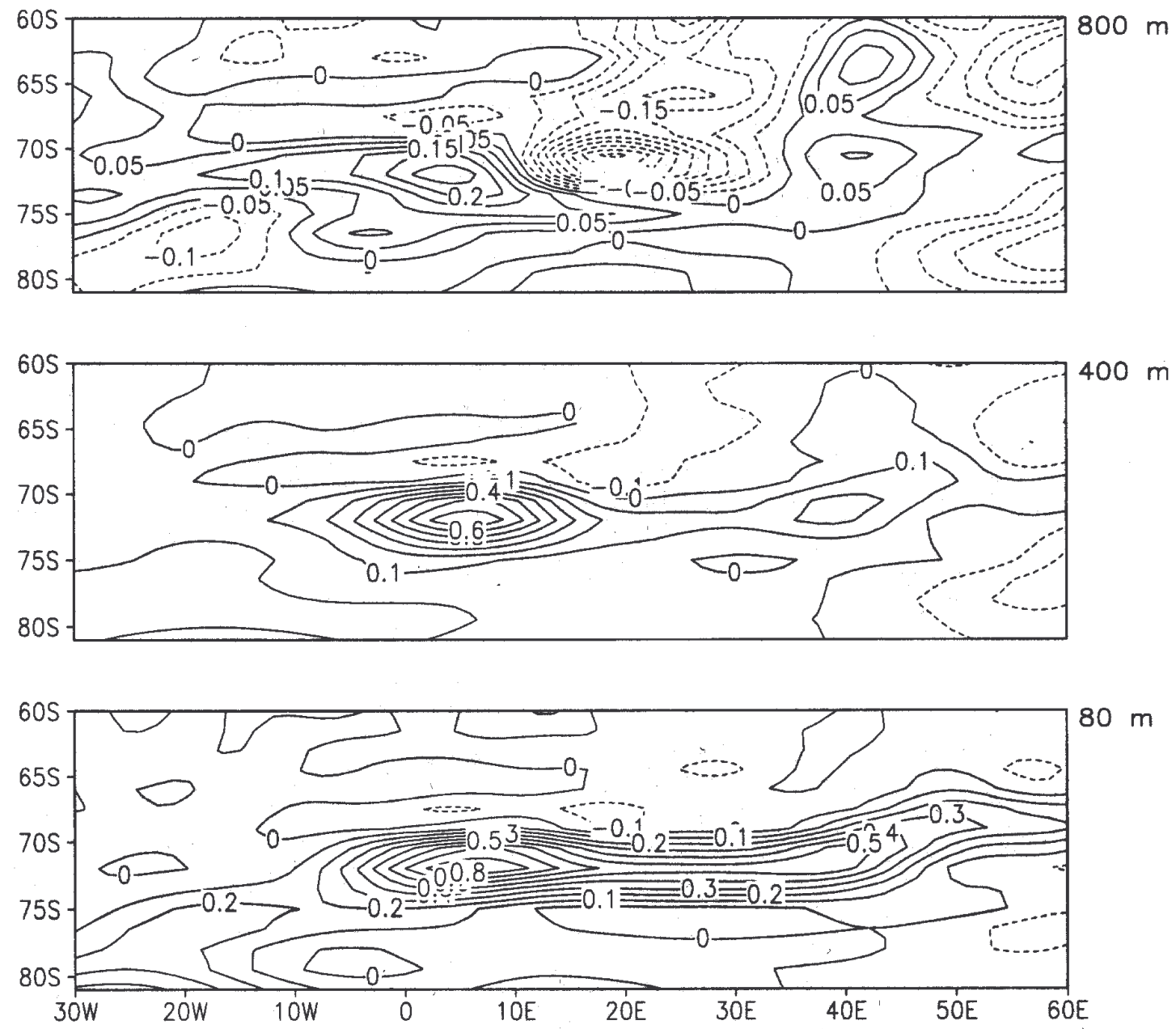

Figure 13. As in figure 7 at 2300 GMT on February 12th, 1997. 
Backward trajectory ending at 09 UTC 12 Feb 97

CDC1 Meteorological Data

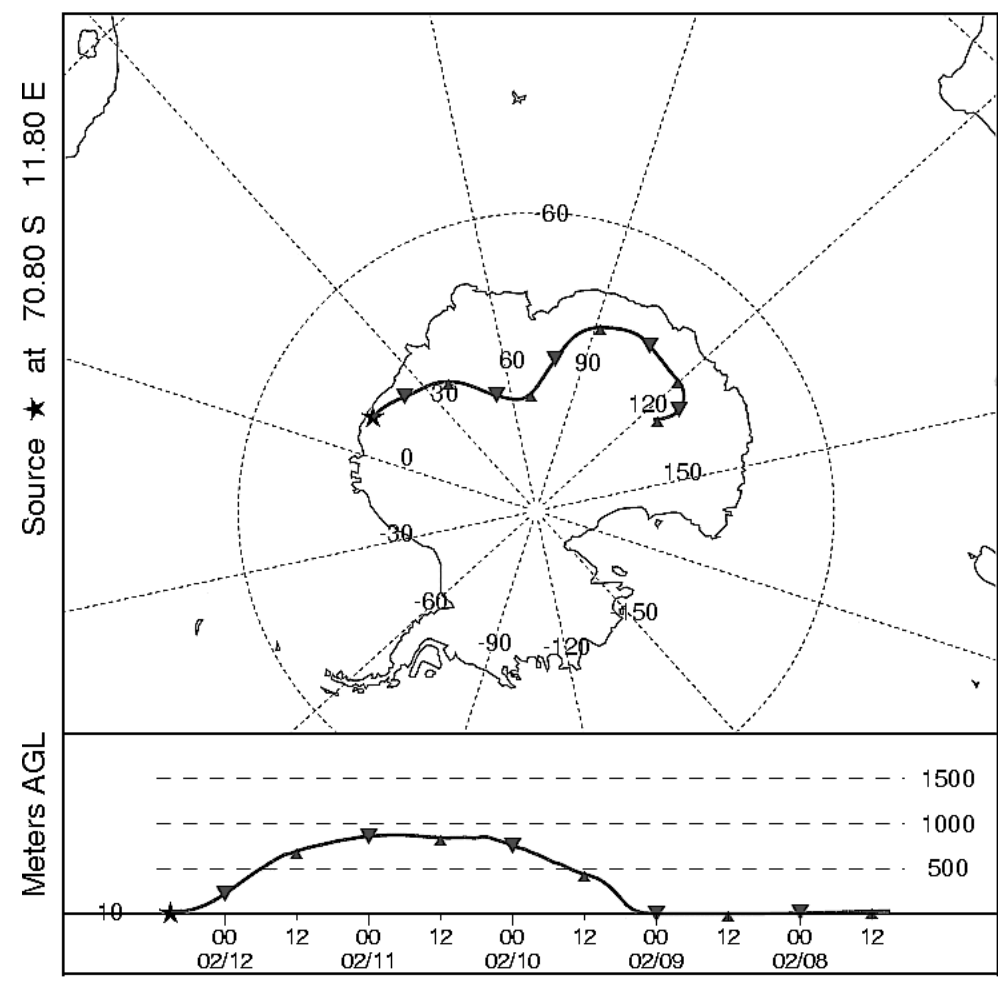

Backward trajectory ending at 00 UTC 13 Feb 97 CDC1 Meteorological Data

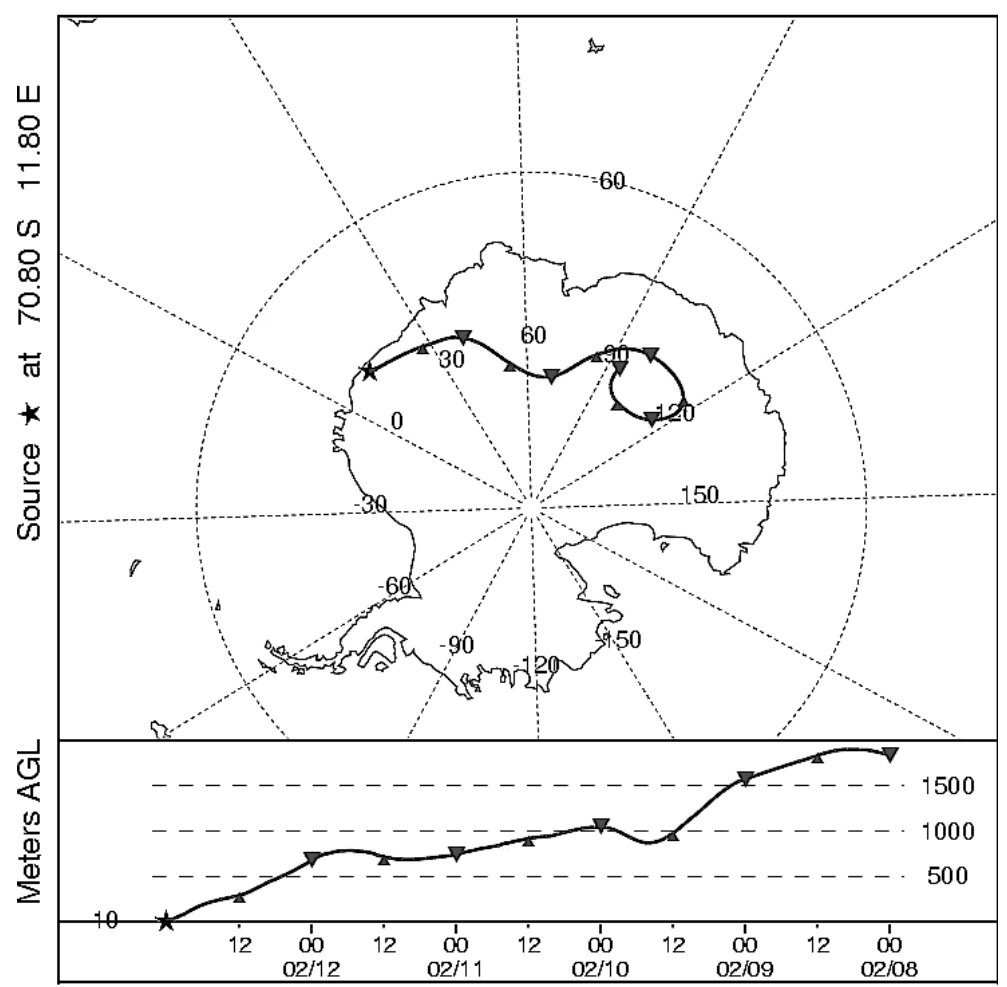

Figure 14. (Continued) 
Backward trajectory ending at 12 UTC 13 Feb 97 CDC1 Meteorological Data

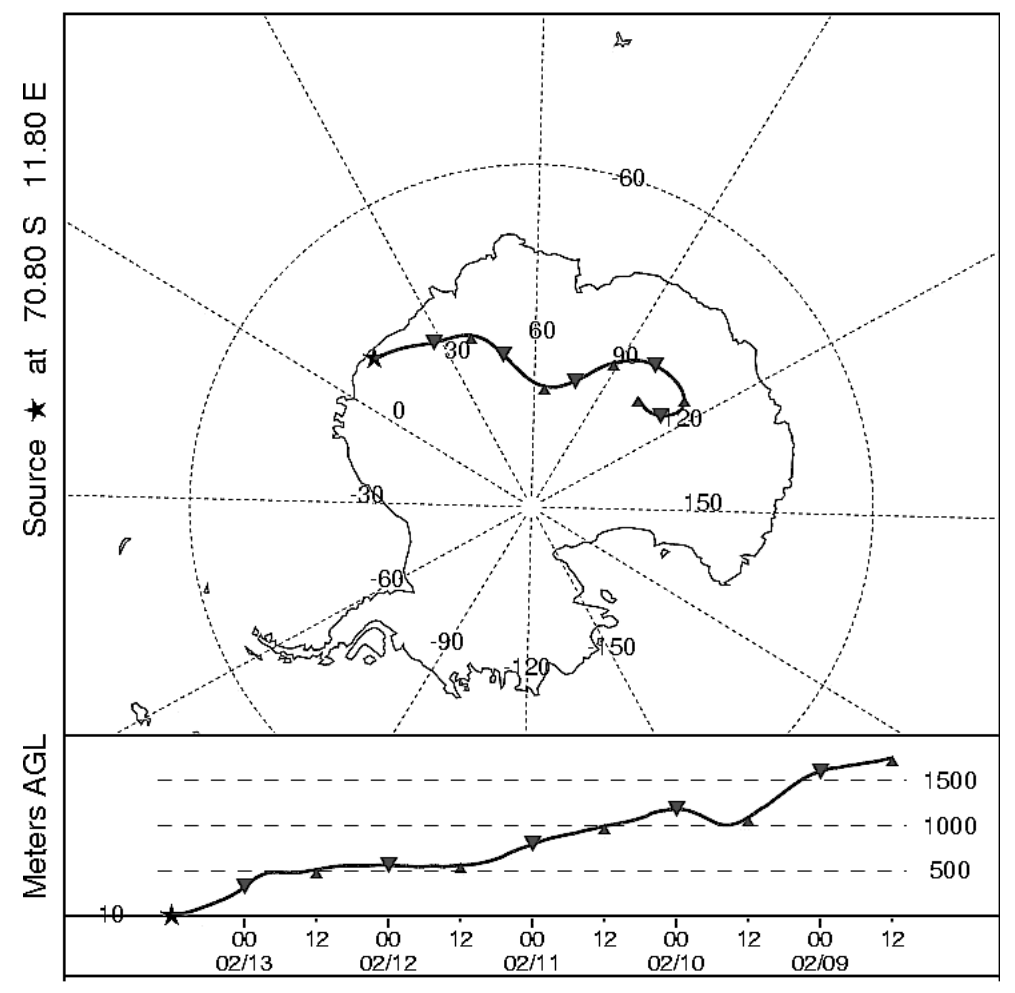

Figure 14. The 5-day back trajectories at 0900 GMT on February 12th, 0000 GMT and 1200 GMT on February 13 th, 1997 at Maitri.

phytoplankton plumes from these sources could be a significant source of $\mathrm{H}_{2} \mathrm{SO}_{4}$ and nucleation mode particles. Emission of trace gases $\left(\mathrm{NH}_{4}\right)$ by penguins may also contribute to aerosol formation at this station.

The aerosol concentrations of $800-1000 \mathrm{~cm}^{-3}$ and the size distributions observed at Maitri in the months of January and February are comparable to those observed at nearby coastal stations, Mawson and Syowa in the same season (Gras and Adriaansen 1985; Ito 1993). Besides the transport of aerosols from lower latitude regions, the gas-toparticle conversion of trace gases and the breaking of waves on the surrounding ocean surfaces are the two possible sources of aerosol generation at Maitri. The processes responsible for the two modes in size distributions are different. The smaller size particles in nucleation mode are mainly due to the nucleation of trace gases. They have only a few days of life time. Observations of Bigg (1980), Bigg et al. [1984], Cadle et al. [1968] and others show that about $95 \%$ of condensation nuclei are sulphate particles, mostly in the form of droplets of sulphuric acid. The strong seasonal variation of such particles observed by Hogan [1975], Shaw [1979] and Ito [1985] may directly relate them to sunlight intensity which indicates to their production by the photochemically derived gas-to- particle conversion. The production of these particles by the gas-to-particle conversion processes is also supported by the fact that excess or nonsea-salt sulphur is found all over the ice sheet at coastal and interior locations and is present mostly as Aitken particles which, as compared to accumulation mode particles, have much smaller residence time in the atmosphere. The process of coagulation substantially contributes to the creation of the accumulation mode. The other possible source for large particles on Antarctica may be the sea-salt particles from bubble breaking at the surrounding sea surface.

The low pressure systems bring in more marine air to Maitri from the regions where DMS emissions are high. The peaks in the total aerosol concentration associated with low pressure system in our measurements may be due to the photochemical production of new particles. The particles may be produced locally or advected from the ice-melt regions brought down by the subsidence of midtropospheric air when the radiative inversion weakens. Our observations of the size distributions of aerosol particles and meteorological conditions associated with such events suggest that these fine particles can grow by the process of condensation, cloud processes and/or coagulation. Also, greater vertical mixing associated with weakening of temperature 
inversion and moderate breeze may enhance the transport of salt particles generated by breaking waves over the sea surface to Maitri.

\section{Acknowledgement}

The authors express their gratitude to the Department of Ocean Development for supporting these studies at Antarctica. The meteorological data provided by the India Meteorological Department is thankfully acknowledged. The authors gratefully acknowledge the NOAA Air Resources Laboratory (ARL) for the provision of the HYSPLIT transport and dispersion model and/or READY website (http://www.arl.noaa.gov/ready.html) used in this publication.

\section{References}

Bates T S, Kapustin V N, Quinn P K, Covert D S, Coffman D J, Mari C, Durkee P A, DeBruyn W and Saltzman E 1998 Processes controlling the distribution of aerosol particles in the lower marine boundary layer during the First Aerosol Characterization Experiment (ACE-1); J. Geophys. Res. 103 16,369-16,384

Bigg E K 1980 Comparison of aerosol at four base-line atmospheric monitoring stations; J. Appl. Meteorol. 19 $521-533$

Bigg E K, Gras J L and Evans C 1984 Origins of Aitken particles in remote regions of the southern hemisphere; J. Atmos. Chem. 1 203-214

Bigg E K, Leek C and Nilsson E D 2001 Sudden changes in aerosol and gas concentrations in the central Arctic marine boundary layer: Causes and consequences; J. Geophys. Res. 106 32,167-32,185

Bourke W, Hart T, Steinle P, Seaman R, Embery G, Naughton M and Rikus L 1995 Evolution of the bureau of meteorology's global assimilation and prediction system, Part 2: resolution enchancements and case studies; Aust. Met. Mag. 44 19-40

Bourke W, Embery G, Harris B, Le T, Naughton M, Paevere J, Rikus L L, Seaman R, Steinle P, Sun Z and Xiao Y 1999 Global assimilation and prediction in the bureau of meteorology; Eleventh Annual BMRC Modelling Workshop, 9-11 November 1999 BMRC Research Report no. 75, Bureau of Meteorology Research Centre, pp 1-7

Cadle R D, Fischer W H, Frank E R and Lodge J P Jr. 1968 Particles in the Antarctic atmosphere; J. Atmos. Sci. 25 100-103

Charlson R J, Lovelock J E, Anreae M O and Warren S G 1987 Oceanic phytoplankton, atmospheric sulfer, cloud albedo and climate; Nature 326 655-661

Clarke A D, Varner J L, Eisele F, Mauldin R L, Tanner D, Litchy M 1998 Particle production in the remote marine atmosphere: cloud outflow and subsidence during ACE-1; J. Geophys. Res. 103 16,397-16,409

Cobb W E and Wells H J 1970 The electrical conductivity of oceanic air and its correlation to global atmospheric pollution; J. Atmos. Sci. $27814-819$

Davison B, O'Dowd C, Hewitt C N, Smith M H, Harrison R M, Peel D A, Wolf E, Mulvaney R, Schwikowski M and Baltensperger U 1996 Dimethyl sulfide and its oxidation products in the atmosphere of the Atlantic and Southern Oceans; Atmos. Environ. 30 1895-1906
Dhanorkar S and Kamra A K 1992 Relation between electrical conductivity and small ion in the presence of intermediate and large ions in the lower atmosphere; J. Geophys. Res. 97 20,345-20,360

Draxler R R and Rolph G D 2003 HYSPLIT (HYbrid Single-Particle Lagrangian Integrated Trajectory) Model access via NOAA ARL READY Website (http://www.arl.noaa.gov/ready/hysplit4.html); NOAA Air Resources Laboratory, Silver Spring, MD.

Fuchs N A 1964 The mechanics of aerosols (Pergamon Press) p. 408

Gras J L and Adriaansen A 1985 Concentration and size variation of condensation nuclei at Mawson, Antarctica; J. Atmos. Chem. 3 96-103

Harvey M J, Fisher G W, Lechner I S, Issac P, Flower N E and Dick A L 1991 Summertime aerosol measurement in the Ross sea region of Antarctica; Atmos. Environ. 25A $569-580$

Hogan A W 1975 Antarctic aerosols; J. App. Met. 14 550559

Hogan A W 1979 Meteorological transport of particulate material to the south polar plateau; J. Appl. Meteorol. 18 741-749

Hoppel W A, Anderson R V and Willet J C 1986 Atmospheric electricity in the planetary boundary layer, In: The Earth's Electrical Environment, pp. 149-165, (Washington, D C.: National Academy Press)

Hoppel W A, Frick G M, Larson R E 1986 Effect of nonprecipitating clouds on the aerosol size distribution in the marine boundary layer; Geophys. Res. Lett. 13 125-128

Hoppel W A, Frick G M, Fitzgerald J W and Larson R E 1994 Marine boundary layer measurements of new particle formation and the effect which non-precipitating clouds have on the aerosol size distribution; J. Geophys. Res. 99 14,442-14,459

Ito T 1980 Observations of atmospheric aerosols at Syowa Station, Antarctica (in Japanese), Tenki Tokyo 27 13-24

Ito T and Iwai K 1981 On the sudden increase in the concentration of Aitken particles in the Antarctic atmosphere; J. Meteorol. Soc. Japan 59 262-271

Ito T 1982 On the size distribution of submicron aerosols in the Antarctic atmosphere; Antarctic Record no. 76 1-19

Ito T 1983 Study on properties and origin of aerosol particles in the Antarctic atmosphere (in Japanese, English abstract); Pap. Meteorol. Geophys. 34(3) 151-219

Ito T 1985 Study of background aerosols in the Antarctic troposphere; J. Atmos. Chem. 3 69-91

Ito T 1993 Size distribution of Antarctic submicron aerosols; Tellus 45B 145-159

Iwai K 1979 Concentration of Aitken particles observed at Syawo station, Antarctica (in Japanese), Nankyoku Shiryo 67 172-179

Jaenicke R and Stingl J 1984 Aitken particle size distribution in Antarctica; In: Proceedings of International Conference on Aerosols and Ice Nuclei, Budapest, (Budapest, Hungary: University of Budapest Press)

Jaenicke R, Dreiling V, Lehmann E, Koutsenoguii P K and Stingl J 1992 Condensation nuclei at the German Antarctic Station 'Georg von Neumayer'; Tellus 44B 311-317

Jaenicke R and Matthias-Maser S 1992 Natural sources of atmospheric aerosol particles, In: Fifth International Conference on Precipitation, Scavenging and Atmos., Surface Exchange Processes

Kamra A K and Deshpande C G 1995 Possible secular change and land-to-ocean extension of air pollution from measurements of atmospheric electrical conductivity over the Bay of Bengal; J. Geophys. Res. 100 7105-7110

Kamra A K, Murugavel P, Pawar S D and Gopalakrishnan V 2001 Background aerosol concentration derived 
from the atmospheric electric conductivity measurements made over the Indian Ocean during INDOEX; J. Geophys. Res. 106 28,643-28,651

Lal M and Kapoor R K 1989 Certain meteorological features of submicron aerosols at Schirmacher oasis, East Antarctica; Atmos. Environ. 23 803-808

Liu B Y H and Pui D Y H 1975 On the performance of the electrical aerosol analyzer; J. Aerosol Science 6 249-264

Misaki M, Ikegami K and Kanazawa J 1972 Atmospheric electrical conductivity measurements in Pacific Ocean exploring the background level of global pollution; $J$. Meteorol. Soc., Jpn. 50 497-500

O'Dowd C D, Geever M, Hill M K, Smith M H and Jennings S G 1998 New particle formation: Nucleation rates and spatial scales in the clean marine coastal environments; Geophys. Res. Lett. 25 1661-1664

O'Dowd C D, MeFiggans G, Creasey D J, Pirjola L, Hoell C, Smith M H, Allan B J, Plane J M C, Heard D E, Lee J D, Pilling M H and Kulmala M 1999 On the photochemical production of new particles in coastal boundary layer; Geophys. Res. Lett 26 1707-1710

Radke L F and Lyons J H 1982 Airborne measurements of particles in Antarctica; In: 2nd symposium on composition of the non-urban troposphere, pp 159-163, American Met. Soc. Massachusetts, USA.
Ramteke D S, Ghode R, Mulay R D and Ghosh T K 1997 Characterisation of selective soil and sediment samples around Indian stations Maitri in Schirmacher Oasis, East Antarctica, Scientific Report Thirteenth Indian Expedition to Antarctica; Tech. Publ. No. 11, Dept. of Ocean Development, 313-321

Rolph G D 2003 Real-time Environmental Applications and Display sYstem (READY) Website (http://www.arl.noaa.gov/ready/hysplit4.html); NOAA Air Resources Laboratory, Silver Spring, MD.

Shaw G E 1979 Consideration on the origin and properties of the Antarctic aerosol; Rev. Geophys. Space Phys. 17 1983-1998

Shaw G E 1986 On the physical properties of aerosol at Ross island, Antarctica; J. Aerosol. Sci. 17 937-945

Shaw G E 1988 Antarctic aerosols: A review; Rev. Geophys. 26 89-112

Voskresenskii A I 1968 Condensation nuclei in the Mirny region; Sov. Antark. Eksped. Trudy 38 149-198

Weber R J, McMurry P H, Mauldin L, Tanner D V, Eiscle F L, Brechtel F J, Kreidenweis S M, Kok G L, Schillawski R D and Bauimgardener D 1998 A study of new particle formation and growth involving biogenic and trace gas spices measured during ACE 1; J. Geophys. Res. 103 16,385-16,396 